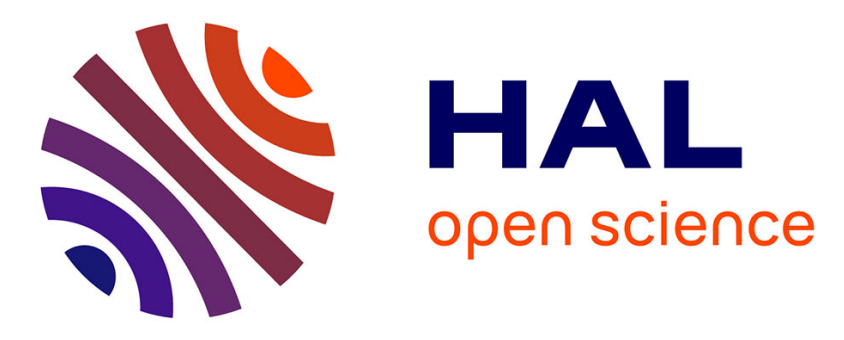

\title{
Evaluation by the double loop electrochemical potentiokinetic reactivation test of aged ferritic stainless steel intergranular corrosion susceptibility
}

\author{
Habib Sidhom, Tidiane Amadou, Chedly Braham
}

\section{- To cite this version:}

Habib Sidhom, Tidiane Amadou, Chedly Braham. Evaluation by the double loop electrochemical potentiokinetic reactivation test of aged ferritic stainless steel intergranular corrosion susceptibility. Metallurgical and Materials Transactions A, 2010, 41 (12), pp.3136-3150. 10.1007/s11661-010-0383-3 . hal-02269243

\section{HAL Id: hal-02269243 \\ https://hal.science/hal-02269243}

Submitted on 22 Aug 2019

HAL is a multi-disciplinary open access archive for the deposit and dissemination of scientific research documents, whether they are published or not. The documents may come from teaching and research institutions in France or abroad, or from public or private research centers.
L'archive ouverte pluridisciplinaire HAL, est destinée au dépôt et à la diffusion de documents scientifiques de niveau recherche, publiés ou non, émanant des établissements d'enseignement et de recherche français ou étrangers, des laboratoires publics ou privés. 


\title{
Evaluation by the Double Loop Electrochemical Potentiokinetic Reactivation Test of Aged Ferritic Stainless Steel Intergranular Corrosion Susceptibility
}

\author{
H. SIDHOM, T. AMADOU, and C. BRAHAM
}

\begin{abstract}
An experimental design method was used to determine the effect of factors that significantly affect the response of the double loop-electrochemical potentiokinetic reactivation (DL-EPR) test in controlling the susceptibility to intergranular corrosion (IGC) of UNS S43000 (AISI 430) ferritic stainless steel. The test response is expressed in terms of the reactivation/activation current ratio $\left(I_{r} / I_{a}\right.$ pct). Test results analysed by the analysis of variance (ANOVA) method show that the molarity of the $\mathrm{H}_{2} \mathrm{SO}_{4}$ electrolyte and the potential scanning rate have a more significant effect on the DL-EPR test response than the temperature and the depassivator agent concentration. On the basis of these results, a study was conducted in order to determine the optimal operating conditions of the test as a nondestructive technique for evaluating IGC resistance of ferritic stainless steel components. Three different heat treatments are considered in this study: solution annealing (nonsensitized), aging during 3 hours at $773 \mathrm{~K}\left(500{ }^{\circ} \mathrm{C}\right)$ (slightly sensitized), and aging during 2 hours at $873 \mathrm{~K}\left(600^{\circ} \mathrm{C}\right)$ (highly sensitized). The aim is to find the operating conditions that simultaneously ensure the selectivity of the attack (intergranular and chromium depleted zone) and are able to detect the effect of low dechromization. It is found that a potential scanning rate of $2.5 \mathrm{mV} / \mathrm{s}$ in an electrolyte composed of $\mathrm{H}_{2} \mathrm{SO}_{4} 3 \mathrm{M}$ solution without depassivator, at a temperature around $293 \mathrm{~K}\left(20^{\circ} \mathrm{C}\right)$, is the optimal operating condition for the DL-EPR test. Using this condition, it is possible to assess the degree of sensitization (DOS) to the IGC of products manufactured in ferritic stainless steels rapidly, reliably, and quantitatively. A time-temperature-start of sensitization (TTS) diagram for the UNS S43000 (France Inox, Villepinte, France) stainless steel was obtained with acceptable accuracy by this method when the IGC sensitization criterion was set to $I_{r} / I_{a}>1$ pct. This diagram is in good agreement with the time-temperature-start of precipitation (TTP) diagram that delineates the domain of low dechromization consecutive to chromium carbide precipitation.
\end{abstract}

\section{INTRODUCTION}

FERRITIC stainless steels are usually used in the manufacturing of steam generators of power plants. These parts are very sensitive to the heat generated by welding, during the maintenance operations, and throughout service aging. The thermal cycles specific to these conditions induce structural changes, by a diffusion mechanism, i.e., the precipitation of chromium carbides and intermetallic phases or without a diffusion mechanism, i.e., the transformation of austenite into martensite during cooling. Such changes may lead, directly or indirectly, to the formation of relatively large depleted chromium zones that are able to sensitize the steel to intergranular corrosion. ${ }^{[1]}$ These phenomena have occurred in several ferritic stainless steel grades

H. SIDHOM, Professor, and T. AMADOU, Lecturer, are with the Laboratoire de Mécanique, Matériaux et Procédés, 1008 Tunis, Tunisia. C. BRAHAM, Senior Lecturer, is with the Laboratoire d'Ingenierie de Materiaux, F75013 Paris, France. Contact e-mail: chedly.braham@paris.ensam.fr

Manuscript submitted July 23, 2009.

Article published online September 3, 2010 such as AISI 430, AISI $430 \mathrm{Ti}$, AISI $430 \mathrm{Nb}$, AISI 434, AISI 444, and AISI 446 after solution annealing (1 hour at $1366 \mathrm{~K}\left(1093{ }^{\circ} \mathrm{C}\right)$ and water or air cooling) and after aging at $1033 \mathrm{~K}\left(760{ }^{\circ} \mathrm{C}\right)$ for 1 hour. ${ }^{[2]}$ They were also observed in the case of AISI 405 at the solution annealed state $\left(0.5\right.$ hours at $1323 \mathrm{~K}\left(1050{ }^{\circ} \mathrm{C}\right)$ and water cooling) and at aged states at temperatures varying between $773 \mathrm{~K}$ and $1123 \mathrm{~K}\left(500{ }^{\circ} \mathrm{C}\right.$ and $\left.850^{\circ} \mathrm{C}\right) .^{[3]}$ The same phenomenon was observed for superferritic stainless steel $\mathrm{X} 1 \mathrm{Cr} 26 \mathrm{Mo}$ aged at temperatures varying from $723 \mathrm{~K}$ to $923 \mathrm{~K}\left(450^{\circ} \mathrm{C}\right.$ to $\left.650^{\circ} \mathrm{C}\right)$ for periods ranging from 2 minutes to 10 hours. ${ }^{[4]}$

The frequently used methods to determine the degree of sensitization to the IGC are either destructive standard tests (ASTM A 262), i.e., Strauss ${ }^{[5]}$ or Huey, ${ }^{[6]}$ which provide qualitative evaluations, or nondestructive tests (ASTM G 108) of the electrochemical double loop-electrochemical potentiokinetic reactivation (DL-EPR $)^{[2-4,7-27]}$ type, which provide a quantitative assessment. However, the ICG assessment by the DL-EPR test is not absolute. Indeed, this evaluation is highly dependent on test operating conditions, such as the nature and the concentration of the electrolyte, the depassivator type, the potential scanning rate, and the 
temperature of the solution. In previous works, authors have optimized and validated the test operating conditions in the case of duplex ${ }^{[8]}$ and austenitic stainless steels. ${ }^{[9]}$ For these materials, the reproducibility of the results, the selectivity of the attack, and the ability of the test to detect the effects of weak dechromizations were clearly confirmed.

In order to continue investigating the optimal operating conditions of the DL-EPR test for a quantitative evaluation of the degree of sensitization (DOS) to the IGC of ferritic stainless steels, the experimental design method was used to determine the effects of the most significant parameters on the response of the DL-EPR test. Selected operating conditions on the basis of the attack selectivity and the ability of the test to detect the effect of low dechromization were performed to establish a time-temperature-start of sensitization (TTS) diagram for the UNS S43000 stainless steel.

\section{MATERIAL, TREATMENTS, AND TESTS}

\section{A. Material and Treatments}

The studied material is the most widely used ferritic stainless steel in the industry: UNS S43000 stainless steel type (AISI 430 or, according to the European standard, $\mathrm{X} 8 \mathrm{Cr} 17)$. Its chemical composition is reported in Table I. The material was received in the form of a 3-mm-thickness sheet.

\section{Annealing treatments}

Two conditions of solution annealing treatments were applied to the studied material:

(1) "air solution annealing": heating at $1373 \mathrm{~K}$ $\left(1100{ }^{\circ} \mathrm{C}\right)$ for 1 hour followed by air cooling, and

(2) "water solution annealing": heating at $1373 \mathrm{~K}$ $\left(1100{ }^{\circ} \mathrm{C}\right)$ for 1 hour followed by water cooling.

\section{Aging treatments}

Aging treatments were performed on samples of water-solution-annealed steel only, at temperatures ranging from $673 \mathrm{~K}$ to $1123 \mathrm{~K}\left(400{ }^{\circ} \mathrm{C}\right.$ to $\left.850{ }^{\circ} \mathrm{C}\right)$ during periods ranging from 5 minutes to 8 hours followed by air cooling.

\section{B. Tests and Criteria}

\section{Microstructural observations}

The phenomena of precipitation that occur during solution annealing or aging treatment were studied by metallographic examinations and by energy-dispersive $\mathrm{X}$-ray microanalysis under scanning electron microscope (SEM).

\section{DL-EPR test and sensitization criteria}

The assessment of the DOS to the IGC of the annealed or aged steel was realized using the DL-EPR test. This electrochemical test consists of monitoring the anodic current $\left(I_{a}\right)$ variation during a scan of the potential $E(\mathrm{mV} / \mathrm{s})$ from an active state of the sample to a passive state, and the reactivation current $\left(I_{r}\right)$ during the return to the active state, using a three electrodes setup. Sensitization to the IGC is evaluated by the ratio $\left(I_{r} / I_{a}\right)$ of anodic $\left(I_{a}\right)$ and reactivation $\left(I_{r}\right)$ current densities or by the ratio of charge densities $\left(Q_{r} / Q_{a}\right)$. The steel is considered as sensitized when the ratio $I_{r} / I_{a} \geq 1$ pct or $Q_{r} / Q_{a} \geq 1$ pct (Figure 1).

\section{Method and criteria for DL-EPR test operating conditions optimization}

The DL-EPR test was performed using an experimental design that varies the concentration of the electrolyte $\left[\mathrm{H}_{2} \mathrm{SO}_{4}\right]$ between 0.1 and $6 \mathrm{M}$, the concentration of the depassivator $\left[\mathrm{NH}_{4} \mathrm{SCN}\right]$ between 0 and $10^{-2} \mathrm{~mol} / \mathrm{L}$, the rate $(d E / d t)$ of the potential scanning (from -500 to $+200 \mathrm{mV} / \mathrm{ECS}$ ) between 0.5 and $5 \mathrm{mV} / \mathrm{s}$, and the temperature of the electrolyte $(T)$ between $293 \mathrm{~K}$ and $308 \mathrm{~K}\left(20^{\circ} \mathrm{C}\right.$ and $\left.35^{\circ} \mathrm{C}\right)$. The electrolyte temperature was controlled using a GRANT stirred thermostatic bath. The electrolyte was stirred without being deaerated.

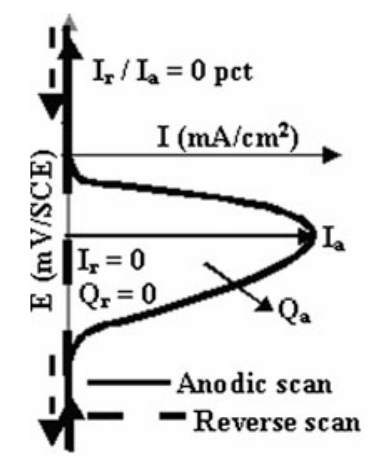

(a)

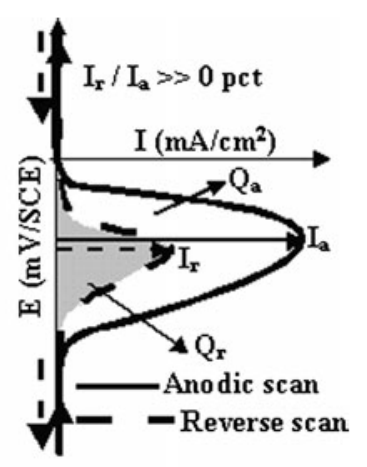

(b)

\begin{tabular}{|c|c|c|}
\multicolumn{3}{c}{} \\
\cline { 2 - 3 } \multicolumn{1}{c|}{ Sensitization criteria $[19]$} \\
\cline { 2 - 3 } \multicolumn{1}{c|}{} & Non sensitized state & Sensitized state \\
\hline $\mathrm{I}_{\mathrm{r}} / \mathrm{I}_{\mathrm{a}}(\%)$ & $<1$ & $\geq 1$ \\
\hline $\mathrm{Q}_{\mathrm{r}} / \mathrm{Q}_{\mathrm{a}}(\%)$ & $<1$ & $\geq 1$ \\
\hline
\end{tabular}

$I_{\mathrm{a}}=$ activation current density

$\mathrm{I}_{\mathrm{r}}=$ reactivation current density

$Q_{\mathrm{Q}}=$ activation charge density

$Q_{x}=$ reactivation charge density

Fig. 1-Principle of DL-EPR technique and IGC sensitization criteria. (a) Non sensitized state. (b) Sensitized state.

Table I. Chemical Composition of UNS S43000 Stainless Steel (Weight Percent)

\begin{tabular}{lccccccc}
\hline Steel Grade & $\mathrm{C}$ & $\mathrm{S}$ & $\mathrm{P}$ & $\mathrm{Si}$ & $\mathrm{Mn}$ & $\mathrm{Cr}$ & $\mathrm{Fe}$ \\
\hline UNS S43000 (EN: X8Cr17) & 0.079 & 0.001 & 0.019 & 0.34 & 0.211 & 16.24 & balance \\
\hline
\end{tabular}


The tests were performed on three different microstructural states that are supposed to cover a wide range of sensitization degrees:

(1) solution annealed with water cooling (expected to be nonsensitized)

(2) aged at $773 \mathrm{~K}\left(500{ }^{\circ} \mathrm{C}\right)$ during 3 hours (supposed to be slightly sensitized), and

(3) aged at $873 \mathrm{~K}\left(600{ }^{\circ} \mathrm{C}\right)$ during 2 hours (supposed to be highly sensitized).

Operating conditions optimization is made on the basis of the detection of significant value of the ratio $I_{r} / I_{a}$ (pct) (proportional to the DOS), acceptable reproducibility (low scatter), good selectivity (intergranular attack exclusively), and very high sensitivity to low DOS (low dechromization).

The DL-EPR test was performed on specimen surfaces that were polished using a 1200 mesh size abrasive paper.

a. Verification of the selectivity of the DL-EPR test. The selectivity of the test is evaluated by SEM examination of sites and forms of corrosion attack under different DL-EPR test conditions. The following criteria were adopted.

(1) The test is considered as selective when the attack is intergranular exclusively.

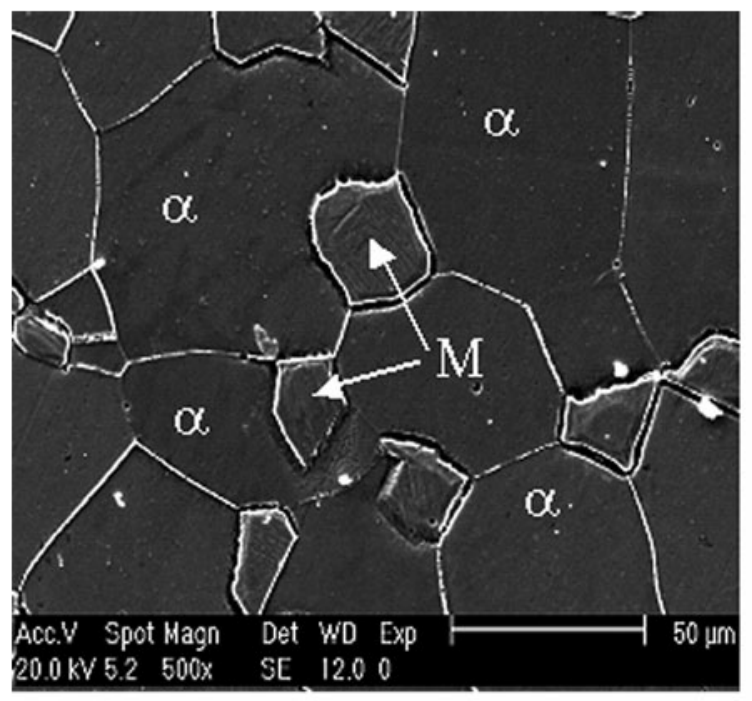

(a)

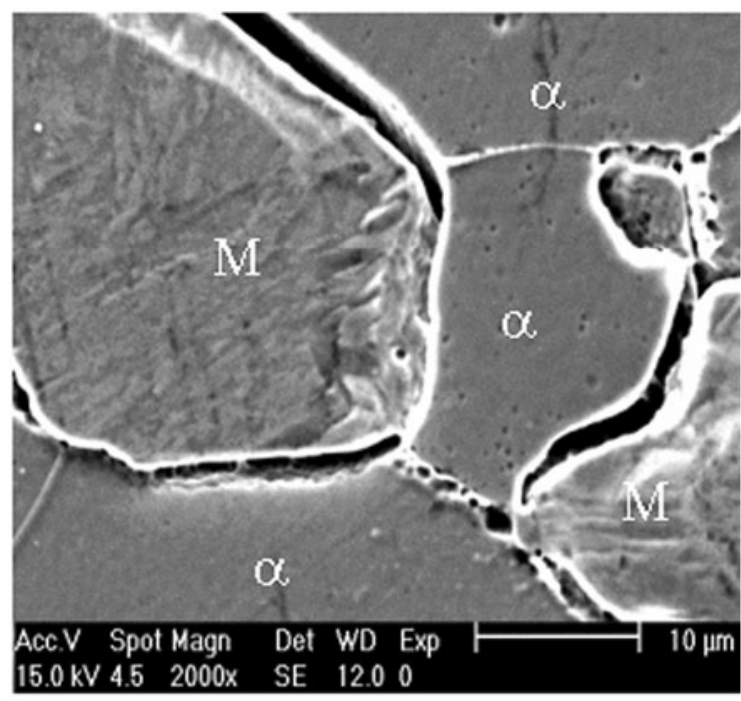

(b)

Fig. 2-Structure after water solution annealing of the UNS S43000 stainless steel. (a) Ferrite + aggregates of austenite transformed into martensite and likely small amount of residual austenite $\left(\gamma_{\text {res }}\right)$. (b) Aggregates of martensite and likely small amount of residual austenite $\left(\gamma_{\text {res }}\right)$ (higher magnification).

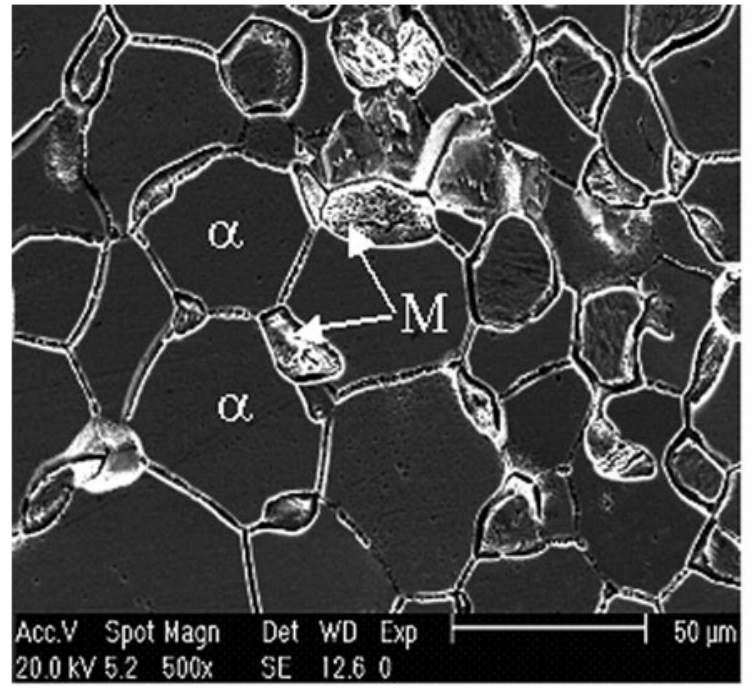

(a)

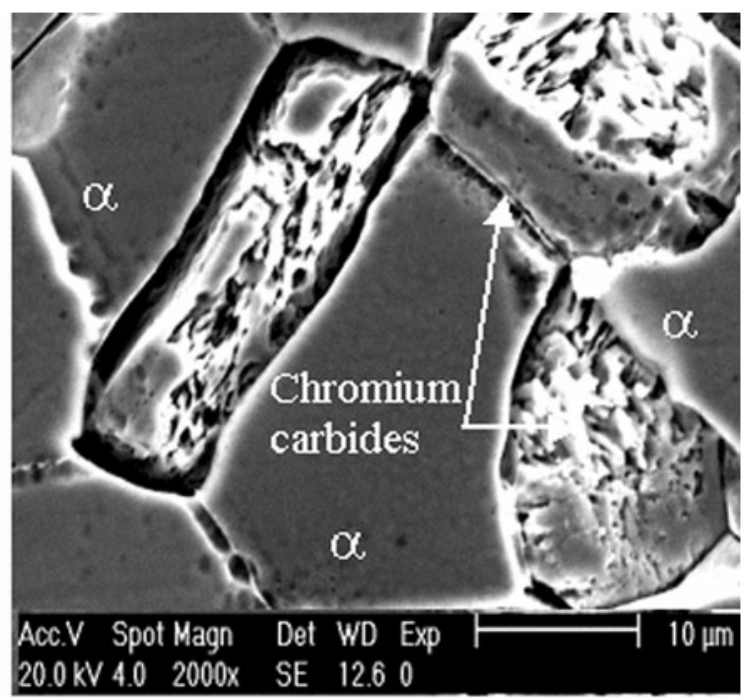

(b)

Fig. 3- Structure after air solution annealing of the UNS S43000 stainless steel. (a) Ferrite (dark) + aggregates austenite transformed into martensile (clear) and likely small amount of residual austenite $\left(\gamma_{\mathrm{res}}\right)$. (b) Precipitation of chromium carbides in aggregates of martensite and in ferritic grain boundaries (higher magnification). 
(2) The test is considered as nonselective when the attack is generalized. This kind of attack is characterized by uniform pitting distribution and additional intercrystalline dissolution.

b. Verification of the DL-EPR sensibility and response conformity. The test sensitivity to detect low dechromization is evaluated by the $\left(I_{r} / I_{a}\right.$ pct) ratio. Its conformity is assessed by the intensity and the depth of the intercrystalline attack, which is qualitatively evaluated by SEM examination. The following criteria were adopted:

(1) step: no intercrystalline attack,

(2) dual: slight intercrystalline attack, and

(3) ditch: high intercrystalline attack.

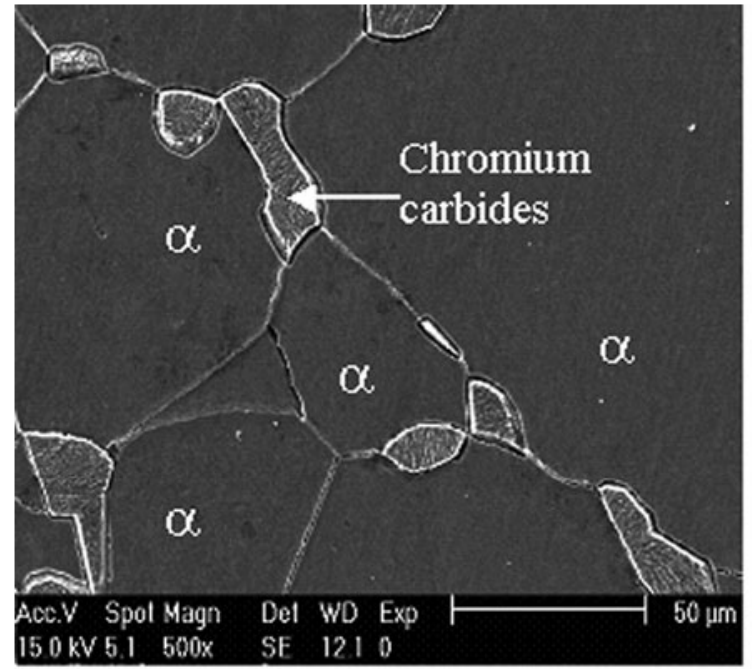

(a)

\section{RESULTS}

\section{A. Microstructure}

1. Microstructure of solution-annealed steel

SEM metallographic examinations of samples annealed at $1373 \mathrm{~K}\left(1100{ }^{\circ} \mathrm{C}\right)$ cooled in water or in air reveal a mixed microstructure consisting of ferrite $(\alpha)$ and aggregates of austenite transformed to carbon supersaturated martensite (M) and likely a small amount of residual austenite $\left(\gamma_{\text {res }}\right)$. Phase partitions are approximately 80 to 90 pct $\alpha$ and 10 to 20 pct aggregates $\left(\mathbf{M}+\gamma_{\text {res }}\right)$. These aggregates result from total or partial transformation of the austenite formed at high temperature in the intercritical area $(\alpha$ and $\gamma)$ during rapid cooling. They appear mainly in the form of islets in the

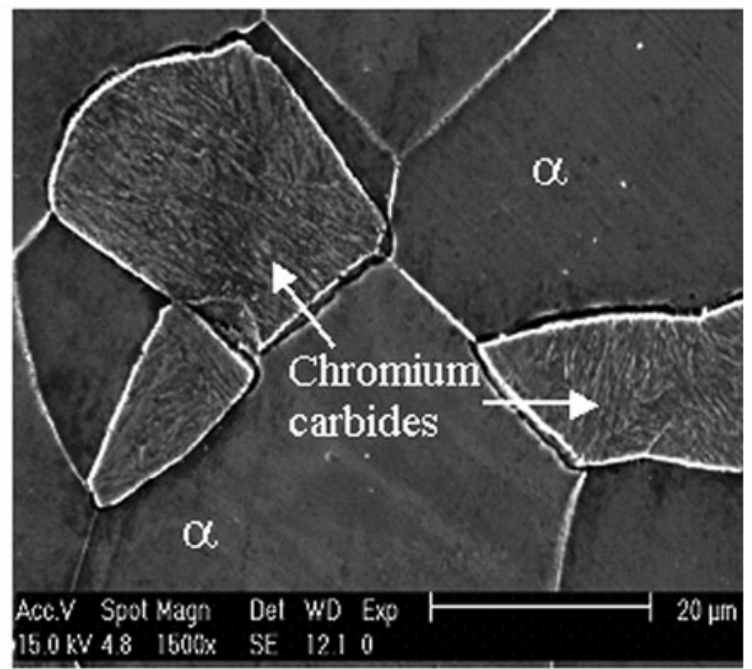

(b)

Fig. 4 Structure of the UNS S43000 stainless steel after aging at $773 \mathrm{~K}\left(500^{\circ} \mathrm{C}\right)$ for $3 \mathrm{~h}$ : very fine decomposition of the quenching martensite into chromium carbides and tempered martensite. (a) Decomposition of quenching martensite into chromium carbides and tempered martensite. (b) Fine decomposition of the quenching martensite into chromium carbides (very weak continuous precipitation (white)) and tempered martensite (higher magnification).

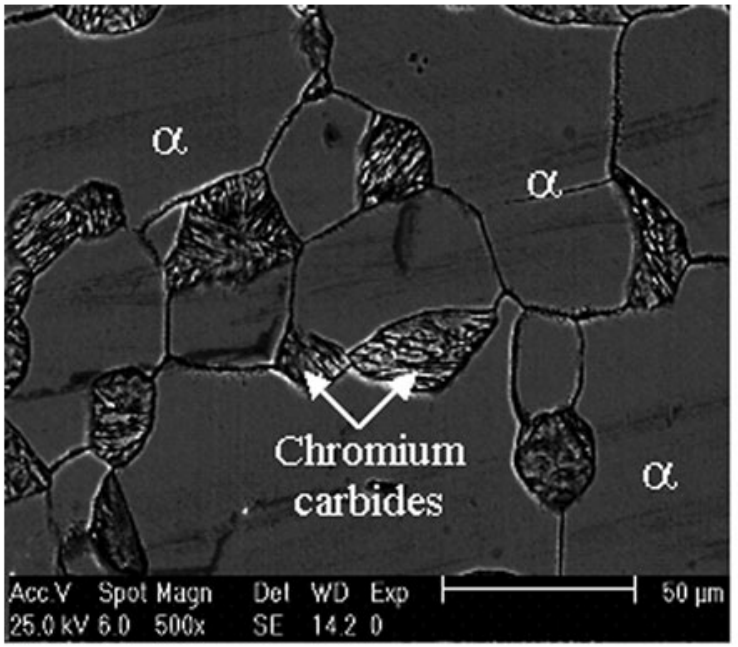

(a)

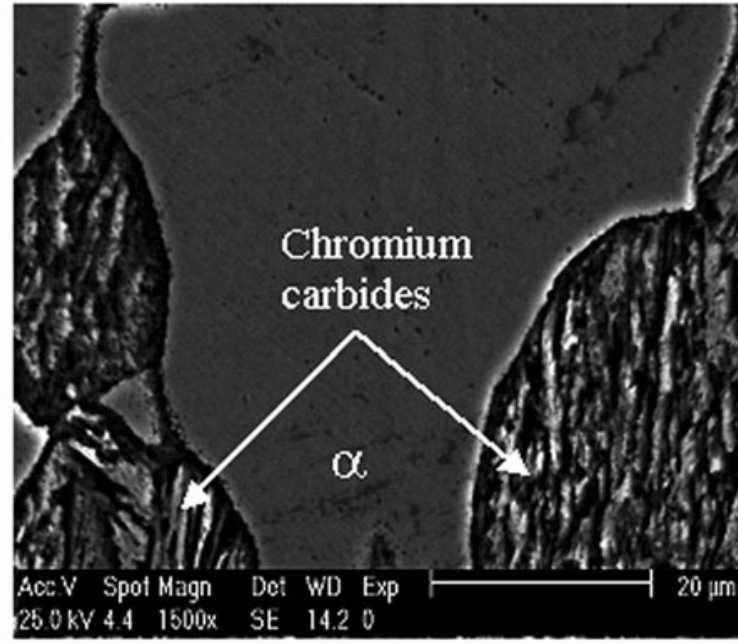

(b)

Fig. 5- Structure of the UNS S43000 stainless steel after aging at $873 \mathrm{~K}\left(600^{\circ} \mathrm{C}\right)$ for $8 \mathrm{~h}$ : resolved decomposition of the martensite into chromium carbides and tempered martensite. (a) Resolved decomposition of aggregates $\left(\mathbf{M}+\gamma_{\text {res }}\right)$ into chromium carbides and tempered martensite. (b) Resolved decomposition of aggregates $\left(\mathbf{M}+\gamma_{\text {res }}\right)$ into chromium carbides and tempered martensite (higher magnification). 
triple points and in the form of weak continuous interface precipitation in the ferritic grain boundaries (Figure 2(a)). At higher magnification, the aggregates of martensite islets and the ferritic grains of the watersolution-annealed steel appear without any perceptible precipitation (Figure 2(b)). This result conforms to the DL-EPR response $\left(I_{r} / I_{a}=0.3 \mathrm{pct}\right)$, which suggests the absence of the chromium-depleted area. However, the airsolution-annealed microstructure $\left(I_{r} / I_{a}=10.25 \mathrm{pct}\right)$ suggests the presence of chromium-depleted zone. This response conforms to the electrolytic attack morphology of martensite and residual austenite aggregates. This seems to be associated with chromium carbide precipitation, resulting from the annealing process during the slow cooling of the supersaturated martensite. Indeed, very weak continuous precipitates, likely chromium carbides, are observed to surround the martensite needles in the aggregates. Additionally, very weak continuous precipitates in the ferritic grain boundaries are observed also (Figure 3).

\section{Microstructure of aged steel}

Aging treatments were performed on samples in the annealed state (annealed at $1373 \mathrm{~K}\left(1100{ }^{\circ} \mathrm{C}\right)$ cooled in water) without previous chromium carbides precipitation or chromium-depleted zones.

The evolution of the microstructure starts always at aggregates of the carbon-supersaturated martensite. Thereafter, it continues at the ferritic grain boundaries and within the ferritic grains when heating is prolonged.

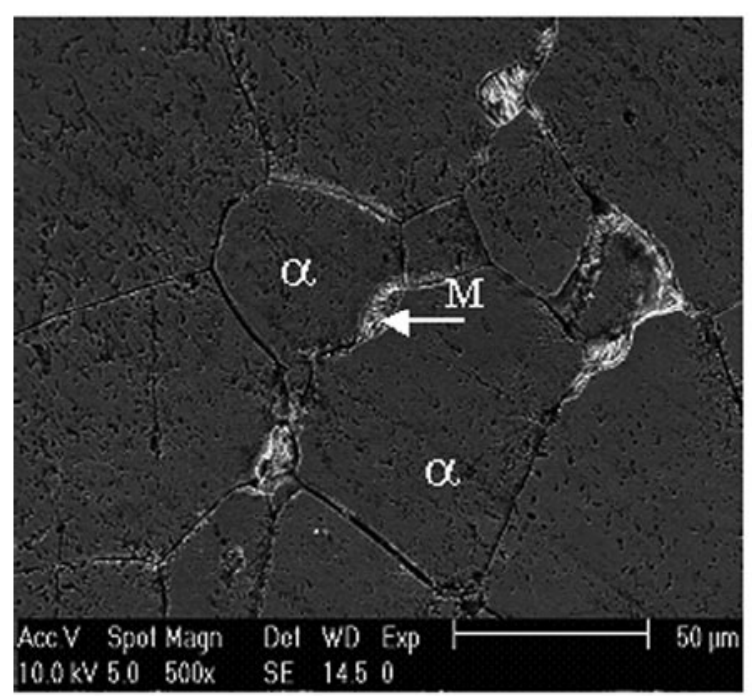

(a)

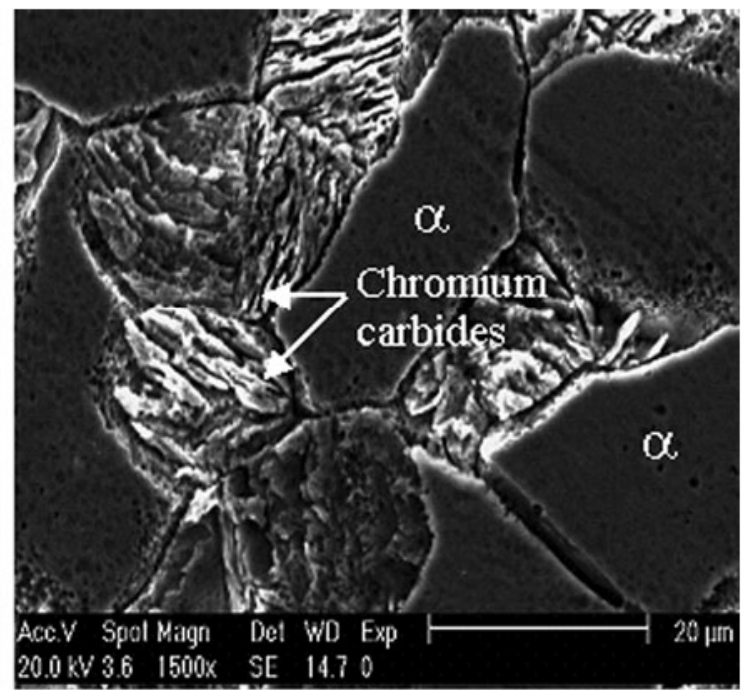

(b)

Fig. 6 - Structure of the UNS S43000 stainless steel after aging at $973 \mathrm{~K}\left(700^{\circ} \mathrm{C}\right)$ for $1 \mathrm{~h} .($ a $)$ Decomposition of the martensite and precipitation of intermettallic phases in ferritic structure. (b) Growth of chromium carbides in the aggregates.

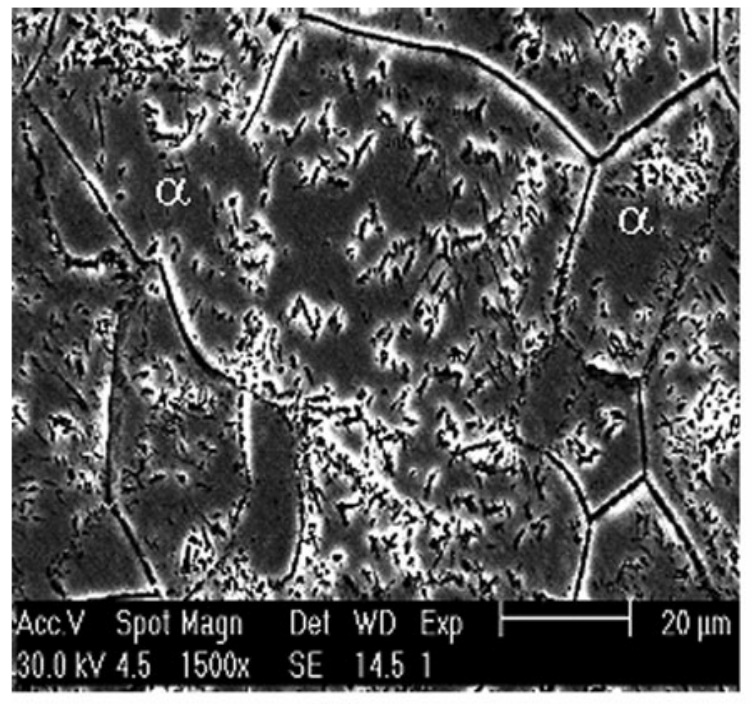

(a)

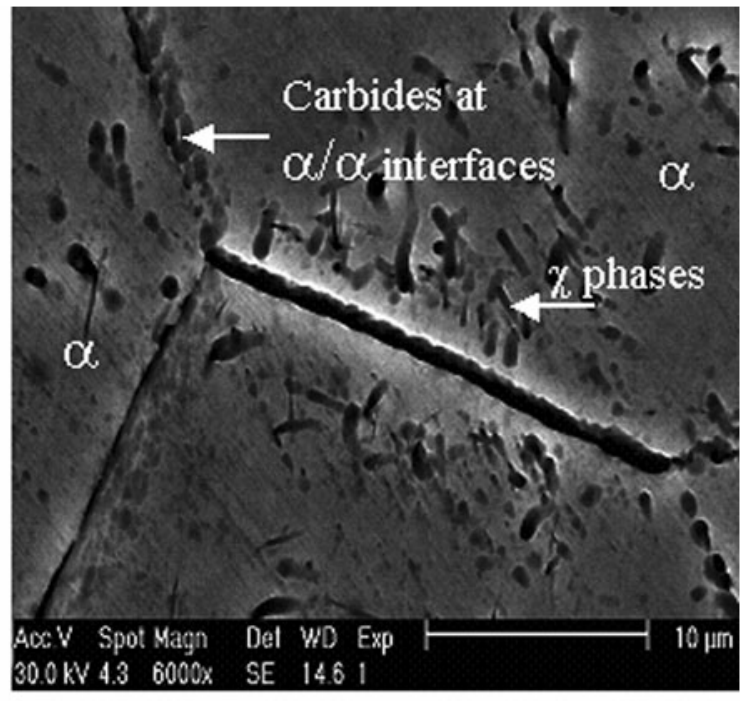

(b)

Fig. 7-Structure of the UNS S43000 stainless steel after aging at $1123 \mathrm{~K}\left(850^{\circ} \mathrm{C}\right)$ for $30 \mathrm{~min}$. (a) Uniform precipitation of intermetallic phases into ferritic matrix. (b) Total decomposition of aggregates and precipitation of carbides and intermetallic phases into ferritic structure. 
The evolution of steel microstructure proceeds at a faster rate at elevated temperatures due to the higher solid-state diffusivity that is favorable for the atomic movement required to achieve the phase changes.

\section{Aging at $773 \mathrm{~K}\left(500{ }^{\circ} \mathrm{C}\right)$}

Heating at $773 \mathrm{~K}\left(500^{\circ} \mathrm{C}\right)$ for less than 3 hours duration did not show any apparent microstructural changes. However, for heating durations exceeding 3 hours, nucleation and growth of chromium carbides resulting from the decomposition of quenched martensite take place in the aggregates. Carbides appear in the form of very weak continuous precipitates (white) at martensite needle interfaces (Figure 4(a)). At higher magnification, this aspect is more obvious (Figure 4(b)).

\section{Aging at $873 \mathrm{~K}\left(600^{\circ} \mathrm{C}\right)$}

At this temperature, the decomposition of martensite into chromium carbides and tempered martensite is faster. For a duration of 15 minutes, weak continuous chromium carbide precipitations at the martensite needle interfaces were revealed. These chromium carbides grow when heating is prolonged. However, no precipitation was observed at the boundaries or within ferritic grains during prolonged heating up to 8 hours at this temperature (Figure 5).

\section{Aging at $973 \mathrm{~K}\left(700^{\circ} \mathrm{C}\right)$}

Heating at this temperature leads to significant reduction of aggregates areas. This reduction occurs gradually to the benefit of chromium carbides and chromium-depleted ferrites. Moreover, uniform precipitation of carbides and intermetallic phases was clearly observed in the ferritic structure (Figure 6). $\chi$ phase precipitates after an aging duration of 10 minutes according to the time-temperature-start of precipitation (TTP) diagram given in Reference 1. For higher

Table II. Design of Experiments for Research of the Effect of Significant Factors on the DL-EPR Test Response $\left(I_{r} / I_{a}\right.$ Pct)

\begin{tabular}{|c|c|c|c|c|c|c|c|c|c|c|c|}
\hline \multirow[b]{3}{*}{$\begin{array}{l}\text { Test } \\
\text { Number }\end{array}$} & \multirow{2}{*}{\multicolumn{4}{|c|}{ Conditions of DL-EPR Test }} & \multirow{3}{*}{$\begin{array}{l}\text { Water Solution } \\
\text { Annealing }(1 \mathrm{~h} \\
\text { at } 1373 \mathrm{~K}\left(1100^{\circ} \mathrm{C}\right) \\
\text { and Water Cooling) } \\
\qquad I_{r} / I_{a} \text { (Pct) }\end{array}$} & \multicolumn{6}{|c|}{ Aging (after Water Solution Annealing) } \\
\hline & & & & & & \multicolumn{3}{|c|}{$\begin{array}{c}3 \mathrm{~h} \text { at } 773 \mathrm{~K} \\
\left(500^{\circ} \mathrm{C}\right)-\text { Air Cooling }\end{array}$} & \multicolumn{3}{|c|}{$\begin{array}{c}2 \mathrm{~h} \text { at } 873 \mathrm{~K} \\
\left(600^{\circ} \mathrm{C}\right) \text {-Air Cooling }\end{array}$} \\
\hline & $\begin{array}{c}d E / d t \\
(\mathrm{mV} / \mathrm{s})\end{array}$ & $\begin{array}{c}{\left[\mathrm{H}_{2} \mathrm{SO}_{4}\right]} \\
(\mathrm{mol} / \mathrm{L})\end{array}$ & $\begin{array}{c}{\left[\mathrm{NH}_{4} \mathrm{SCN}\right]} \\
(\mathrm{mol} / \mathrm{L})\end{array}$ & $\begin{array}{l}T \mathrm{~K} \\
\left({ }^{\circ} \mathrm{C}\right)\end{array}$ & & $\begin{array}{c}I_{a} \\
\left(\mathrm{~mA} / \mathrm{cm}^{2}\right)\end{array}$ & $\begin{array}{c}I_{r} \\
\left(\mathrm{~mA} / \mathrm{cm}^{2}\right)\end{array}$ & $\begin{array}{l}I_{r} / I_{a} \\
(\mathrm{Pct})\end{array}$ & $\begin{array}{c}I_{a} \\
\left(\mathrm{~mA} / \mathrm{cm}^{2}\right)\end{array}$ & $\begin{array}{c}I_{r} \\
\left(\mathrm{~mA} / \mathrm{cm}^{2}\right)\end{array}$ & $\begin{array}{l}I_{r} / I_{a} \\
(\mathrm{Pct})\end{array}$ \\
\hline 1 & 0.5 & 0.1 & 0 & $293(20)$ & 0 & 8.2 & $<0$ & 0 & 15.41 & 1.41 & 9.14 \\
\hline 2 & 5 & 0.1 & 0 & $293(20)$ & 0 & 8.6 & $<0$ & 0 & 18.23 & $<0$ & 0 \\
\hline 3 & 0.5 & 6 & 0 & $293(20)$ & 78.87 & 48.34 & 52.44 & 108.48 & 59.21 & 54.51 & 92.06 \\
\hline 4 & 5 & 6 & 0 & $293(20)$ & 36.98 & 48.27 & 13.92 & 28.83 & 54.31 & 21.26 & 39.14 \\
\hline 5 & 0.5 & 0.1 & 0.01 & 293 (20) & 25.83 & 82.71 & 23.53 & 28.44 & 71.25 & 15.01 & 21.06 \\
\hline 6 & 5 & 0.1 & 0.01 & $293(20)$ & 14.86 & 96.69 & 10.82 & 10.85 & 73.27 & 14.39 & 19.64 \\
\hline 7 & 0.5 & 6 & 0.01 & $293(20)$ & 96.58 & 118.58 & 78.3 & 66.03 & 174.58 & 180.33 & 103.29 \\
\hline 8 & 5 & 6 & 0.01 & $293(20)$ & 31.67 & 160.01 & 93.24 & 58.27 & 203.86 & 162.85 & 79.88 \\
\hline 9 & 0.5 & 0.1 & 0.01 & $308(35)$ & 27.02 & 77.13 & 19.07 & 24.72 & 71.12 & 21.42 & 28.51 \\
\hline 10 & 5 & 0.1 & 0.01 & $308(35)$ & 20.46 & 76.88 & 7.75 & 10.21 & 80.53 & 12.34 & 15.32 \\
\hline 11 & 0.5 & 6 & 0.01 & $308(35)$ & 57.45 & 220.19 & 162.34 & 73.73 & 207.53 & 216.45 & 104.29 \\
\hline 12 & 5 & 6 & 0.01 & 308 (35) & 29.35 & 357.17 & 166.44 & 46.59 & 510.95 & 297.18 & 58.16 \\
\hline 13 & 0.5 & 0.1 & 0 & $308(35)$ & 8.63 & 21.93 & 3.53 & 16.09 & 8.99 & 3.06 & 34.03 \\
\hline 14 & 5 & 0.1 & 0 & $308(35)$ & 0 & 42.4 & 1.91 & 4.5 & 45.04 & 0.24 & 0.53 \\
\hline 15 & 0.5 & 6 & 0 & $308(35)$ & 36.4 & 266.62 & 229.72 & 86.16 & 211.8 & 127.90 & 60.39 \\
\hline 16 & 5 & 6 & 0 & $308(35)$ & 16.51 & 218.22 & 104.71 & 47.98 & 152.56 & 49.23 & 32.26 \\
\hline
\end{tabular}

Table III. Results of the Analysis by the ANOVA Method

\begin{tabular}{|c|c|c|c|c|}
\hline State & Range of Validity & Model & $\begin{array}{l}\text { Reliability } \\
\text { (Pct) }\end{array}$ & $\begin{array}{l}\text { Significant } \\
\text { Factor* }\end{array}$ \\
\hline $\begin{array}{l}1373 \mathrm{~K}\left(1100^{\circ} \mathrm{C}\right)-1 \mathrm{~h}-\text { water } \\
\text { cooling (nonsensitized) }\end{array}$ & $\begin{array}{l}0 \leq d E / d t(\mathrm{mV} / \mathrm{s}) \leq 0.5 \\
0 \leq \mathrm{H}_{2} \mathrm{SO}_{4}(\mathrm{M}) \leq 6 \\
0 \leq \mathrm{NH}_{4} \mathrm{SCN}(\mathrm{M}) \leq 0.01 \\
293 \mathrm{~K}\left(20{ }^{\circ} \mathrm{C}\right) \leq T\left({ }^{\circ} \mathrm{C}\right)\end{array}$ & $\begin{array}{l}I_{r} / I_{a}=38.4472+5.9794 \cdot \mathrm{H}_{2} \mathrm{SO}_{4} \\
\quad-5.0264 \cdot d E / d t+1572.87 \cdot \mathrm{NH}_{4} \mathrm{SCN} \\
\quad-0.7414 \cdot T\end{array}$ & 76.45 & $\begin{array}{l}\mathrm{H}_{2} \mathrm{SO}_{4}: 0.0008 \\
d E / d t: 0.0144 \\
\mathrm{NH}_{4} \mathrm{SCN}: 0.0687 \\
T: 0.1814\end{array}$ \\
\hline $\begin{array}{l}773 \mathrm{~K}\left(500^{\circ} \mathrm{C}\right)-2 \mathrm{~h} \text {-air cooling } \\
\text { (slightly sensitized) }\end{array}$ & $\leq 308 \mathrm{~K}\left(35^{\circ} \mathrm{C}\right)$ & $\begin{array}{l}I_{r} / I_{a}=23.0997+8.7763 \cdot \mathrm{H}_{2} \mathrm{SO}_{4} \\
\quad-5.4561 \cdot d E / d t+335.0 \cdot \mathrm{NH}_{4} \mathrm{SCN} \\
\quad+0.0757 \cdot T\end{array}$ & 83.22 & $\begin{array}{l}\mathrm{H}_{2} \mathrm{SO}_{4}: 0.0000 \\
d E / d t: 0.0098 \\
\mathrm{NH}_{4} \mathrm{SCN}: 0.6789 \\
T: 0.8881\end{array}$ \\
\hline $\begin{array}{l}873 \mathrm{~K}\left(600^{\circ} \mathrm{C}\right)-3 \mathrm{~h} \text {-air cooling } \\
\text { (highly sensitized) }\end{array}$ & & $\begin{array}{l}I_{r} / I_{a}=28.7829+9.1925 \cdot \mathrm{H}_{2} \mathrm{SO}_{4} \\
\quad-5.7733 \cdot d E / d t+2032.5 \cdot \mathrm{NH}_{4} \mathrm{SCN} \\
\quad-0.256 \cdot T\end{array}$ & 88.67 & $\begin{array}{l}\mathrm{H}_{2} \mathrm{SO}_{4}: 0.0000 \\
d E / d t: 0.0032 \\
\mathrm{NH}_{4} \mathrm{SCN}: 0.0137 \\
T: 0.5910\end{array}$ \\
\hline
\end{tabular}

*Significant factor: determined by the probability of being on the null hypothesis $(<0.05) .{ }^{[28]}$ 


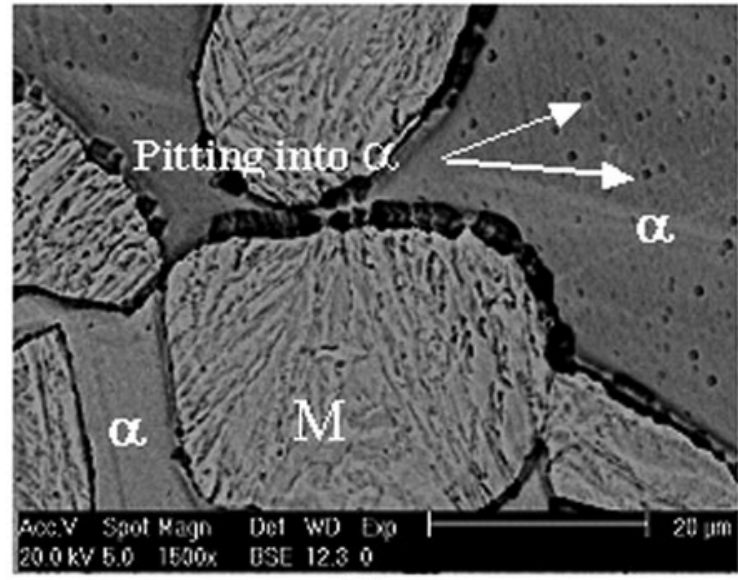

(a)

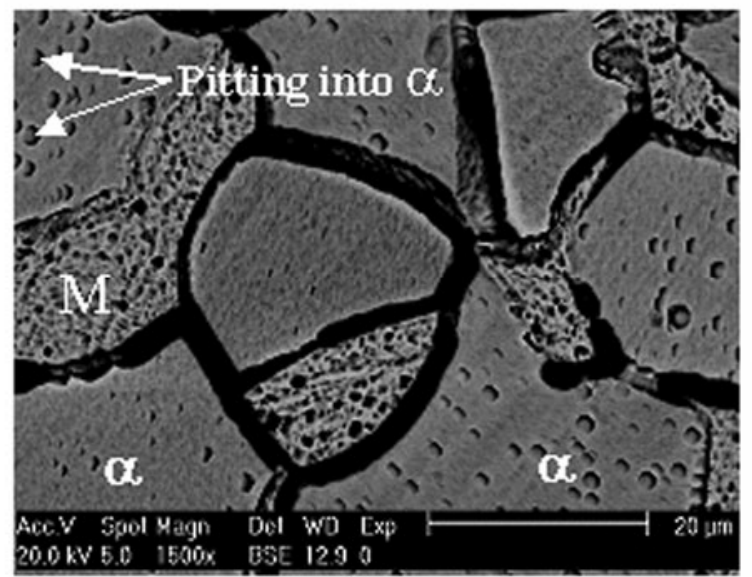

(b)

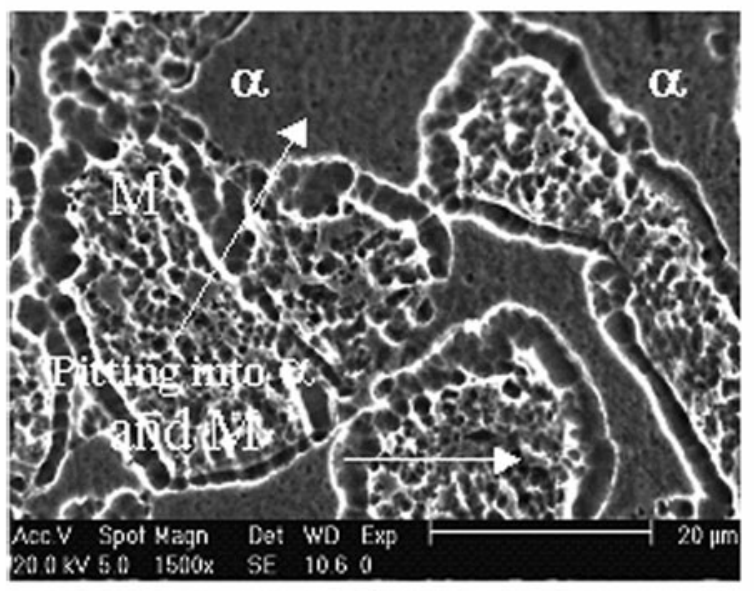

(c)

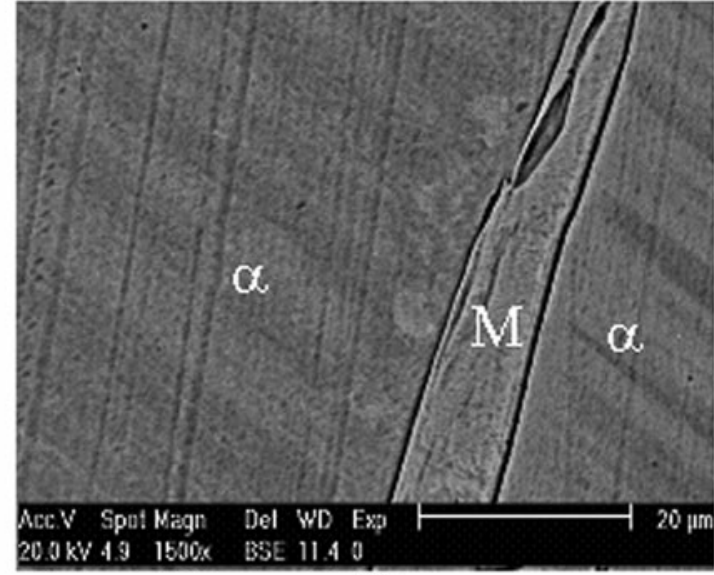

(d)

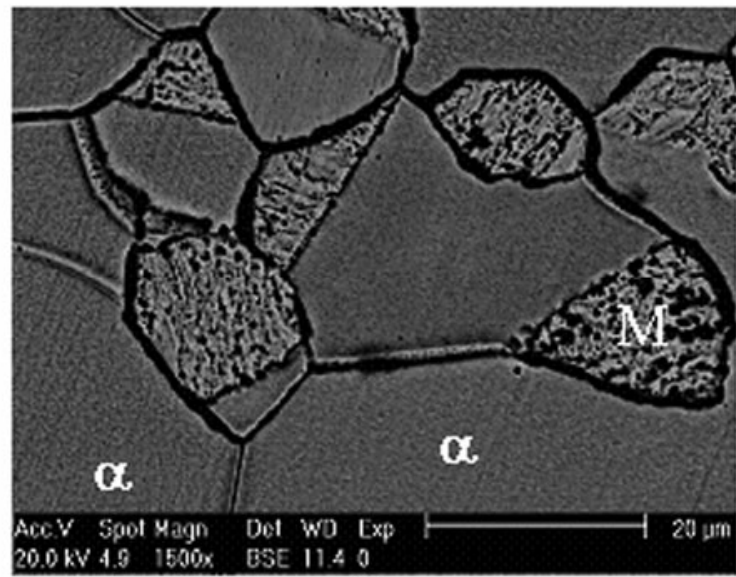

(e)

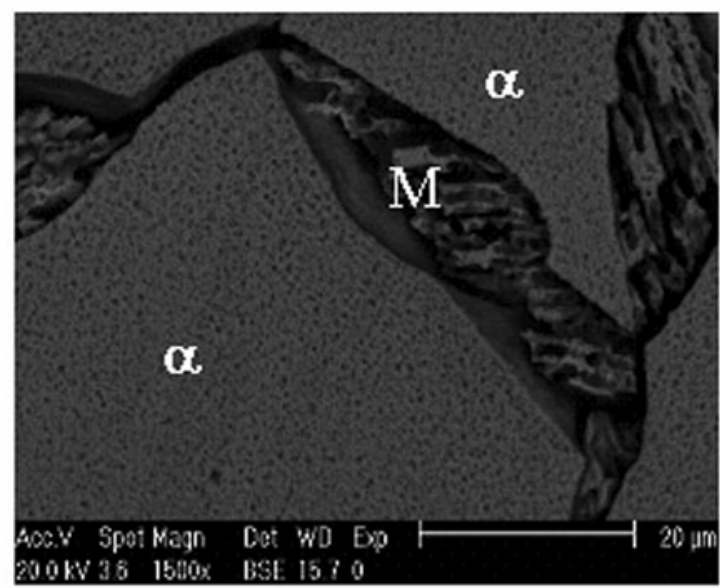

(f)

Fig. 8-Effect of the electrolyte concentration on the selectivity of the attack after DL-EPR testing under $2.5 \mathrm{mV} / \mathrm{s}$ and at $293 \mathrm{~K}\left(20{ }^{\circ} \mathrm{C}\right)$. (a) $\mathrm{H}_{2} \mathrm{SO}_{4} 6 \mathrm{M}$ (uniform attack). Solution annealed steel (non sensitized). (b) $\mathrm{H}_{2} \mathrm{SO}_{4} 6 \mathrm{M}$ (uniform attack). Steel aged at $773 \mathrm{~K}\left(500{ }^{\circ} \mathrm{C}\right.$ ) for $3 \mathrm{~h}$ (slightly sensitized). (c) $\mathrm{H}_{2} \mathrm{SO}_{4} 6 \mathrm{M}$ (uniform attack). Steel aged at $873 \mathrm{~K}\left(600{ }^{\circ} \mathrm{C}\right.$ ) for $2 \mathrm{~h}$ (highly sensitized). (d) $\mathrm{H}_{2} \mathrm{SO}_{4} 3 \mathrm{M}$ (selective attack). Solution annealed steel (non sensitized). (e) $\mathrm{H}_{2} \mathrm{SO}_{4} 3 \mathrm{M}$ (selective attack). Steel aged at $773 \mathrm{~K}\left(500{ }^{\circ} \mathrm{C}\right.$ ) for $3 \mathrm{~h}$ (slightly sensitized). $(f) \mathrm{H}_{2} \mathrm{SO}_{4}$ $3 \mathrm{M}$ (selective attack). Steel aged at $873 \mathrm{~K}\left(600^{\circ} \mathrm{C}\right)$ for $2 \mathrm{~h}$ (highly sensitized).

temperature $1073 \mathrm{~K}\left(800^{\circ} \mathrm{C}\right)$ and 5 hours duration, $\sigma$ phase precipitates. Both phases are rich in chromium.

\section{Aging at $1123 \mathrm{~K}\left(850^{\circ} \mathrm{C}\right)$}

The decomposition of aggregates seems to be total at this temperature after durations as short as 30 minutes.
This decomposition leads to a microstructure characterized by carbides and intermetallic phases in the ferritic structure grain and at the ferritic grain boundaries (Figure 7(a)). Such continuous precipitation of carbides in the ferritic grain boundaries creates dechromized areas with a width equal or less than $4 \mu \mathrm{m}$ (Figure 7(b)). 


\section{B. Optimization of Operating Conditions of the DL-EPR Tests}

The DL-EPR test responses obtained with the operating conditions for solution-annealed state (nonsensitized) and aged state (sensitized) are clearly described by the values of the $I_{r} / I_{a}$ (pct) ratio, as reported in Table II. These responses indicate aberrant detections of IGC sensitization of the solution-annealed state for operating conditions of test $7\left(I_{r} / I_{a}=96.58 \mathrm{pct}\right)$ and of desensitization of the aged steel at $873 \mathrm{~K}\left(600{ }^{\circ} \mathrm{C}\right)$ for 2 hours corresponding to test $2\left(I_{r} / I_{a}=0 \mathrm{pct}\right)$.

Quantitative analysis of these experimental results, reported in Table III, using the ANOVA method provides the main operating factors controlling the responses of the DL-EPR test. They reveal the significant effect of the electrolyte molarity and the potential scanning rate, regarding the degree of sensitization of the sample. These two factors have the most significant contributions in the DL-EPR test response expressed by the $I_{r} / I_{a}$ (pct) ratio as their probability of being at the zero hypotheses, i.e., variances is lower than 5 pct.

Depassivator concentration and electrolyte temperature seem to have much smaller effects on this ratio, as shown in Table III. The reliability of each relationship in the range of variation of each factor is given also in the same table. These values are below 100 pct because the effects of interactions between factors were not taken into account in these relationships. The linear model was selected because it is simple to develop (linear regression) and it offers acceptable reliability $(\approx 80 \mathrm{pct})$ compared with the experimental error (Table III).

The effects of the significant factors on the selectivity of the test were established on the basis of SEM examinations of the attack forms resulting from the DL-EPR tests, for each operating condition. Similarly, the sensitivity of the test in detecting low dechromizations has been established on the basis of the conformity of the attack intensity with the $I_{r} / I_{a}$ (pct) value and the microstructural changes. The following results were obtained.

\section{Effect of the electrolyte $\left(\mathrm{H}_{2} \mathrm{SO}_{4}\right)$ concentration}

The results of the experimental design show that the $\left(I_{r} / I_{a}\right.$ pct) ratio increases significantly with the molarity of the electrolyte while other operating conditions are kept constant. The DL-EPR tests, carried out without the depassivator at constant potential scanning rate of $2.5 \mathrm{mV} / \mathrm{s}$ and constant temperature of $293 \mathrm{~K}\left(20^{\circ} \mathrm{C}\right)$, show that the $I_{r} / I_{a}$ ratio varies when the molarity of $\mathrm{H}_{2} \mathrm{SO}_{4}$ electrolyte varies from 3 to $6 \mathrm{M}$. The microstructure observations indicate the following.

(1) For water-solution-annealed (nonsensitized) specimens, the $I_{r} / I_{a}$ ratio increases from 0.3 (under optimal condition using $3 \mathrm{M}$ ) to 10 pet (under optimal condition using $6 \mathrm{M}$ ).

(2) For aged specimens during 3 hours at $773 \mathrm{~K}$ $\left(500^{\circ} \mathrm{C}\right)$ (low sensitized), the $I_{r} / I_{a}$ ratio increases from 2.6 (under optimal condition using $3 \mathrm{M}$ ) to 13 pct (under optimal condition using $6 \mathrm{M}$ ).

(3) For aged specimens during 2 hours at $873 \mathrm{~K}$ $\left(600{ }^{\circ} \mathrm{C}\right)$ (highly sensitized), the $I_{r} / I_{a}$ ratio increases from 33 (under optimal condition using $3 \mathrm{M}$ ) to 39 pct (under optimal condition using $6 \mathrm{M}$ ).

The rise of the current ratio coupled with the increase of the reactivation current density means that the repassivation kinetics in more concentrated electrolyte (6 M) are much slower and that the attack is uniform. This attack is characterized by a large distribution of corrosion pits for the solution-annealed state (Figure 8(a)) as well as for the low sensitized (Figure 8(b)) and highly sensitized (Figure 8(c)) states. However, the attack is selectively preserved at molarities of the electrolyte less than or equal to $3 \mathrm{M}$ for the three states (Figures 8(d) through (f)). The attack appears in conformity with the microstructure (large chromium-depleted zones) and the response test:

(1) step for $\left(I_{r} / I_{a}=0.3 \mathrm{pct}\right)$ for the solution-annealed state (nonsensitized)

(2) dual for $\left(I_{r} / I_{a}=2.6 \mathrm{pct}\right)$ for the low sensitized state, and

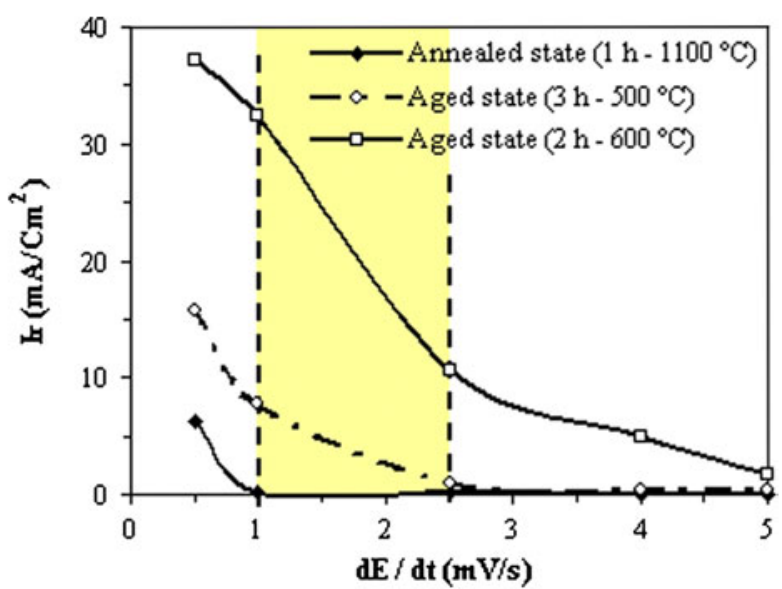

(a)

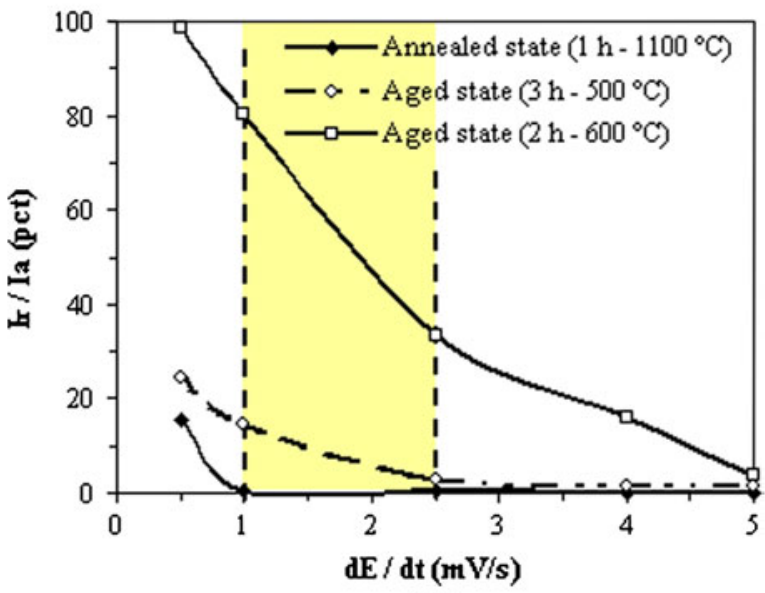

(b)

Fig. 9-Influence of the potential scanning rate on the repassivation kinetics and the DL-EPR test response $\left(I_{r} / I_{a}\right.$ pct); test carried out with a $3 \mathrm{M}$ solution of $\mathrm{H}_{2} \mathrm{SO}_{4}$ at the temperature of $293 \mathrm{~K}\left(20^{\circ} \mathrm{C}\right)$. (a) Effect of the potential scanning rate on the repassivation kinetics $\left(I_{r}\right.$ in $\left.\mathrm{mA} / \mathrm{cm}^{2}\right)$. (b) Effect of the potential scanning rate on the DL-EPR test response $\left(I_{r} / l_{a}\right.$ pct). 
(3) ditch for $\left(I_{r} / I_{a}=33 \mathrm{pct}\right)$ for the highly sensitized state.

This concentration of sulfuric acid ( $3 \mathrm{M}$ ) will now be used for the assessment by the DL-EPR test of the degree of sensitization to the IGC of ferritic stainless steels.

\section{Effect of potential scanning rate}

The reactivity of surfaces, expressed by the reactivation current density $\left(I_{r}\right)$, for annealed solution state and aged states in the electrolyte without depassivator and composed of a $3 \mathrm{M} \mathrm{H}_{2} \mathrm{SO}_{4}$ solution at a temperature of $293 \mathrm{~K}\left(20^{\circ} \mathrm{C}\right)$, increases when the potential scanning rate $(d E / d t)$ decreases from 5 to $0.5 \mathrm{mV} / \mathrm{s}$ (Figure 9(a)). The same evolution is observed for the DL-EPR test response, expressed by the $I_{r} / I_{a}$ (pct) ratio (Figure 9(b)).

The results of attack form examinations and comparison with the change in the $I_{r} / I_{a}$ ratio reveal the existence of three fields of potential scanning rates.

(1) Range of high scanning rates $(d E / d t>2.5 \mathrm{mV} / \mathrm{s})$ : The test is insensitive to the dechromization phenomena. In this case, the kinetics of electrochemical reactions were very slow compared to the kinetics of potential scanning. That is why the
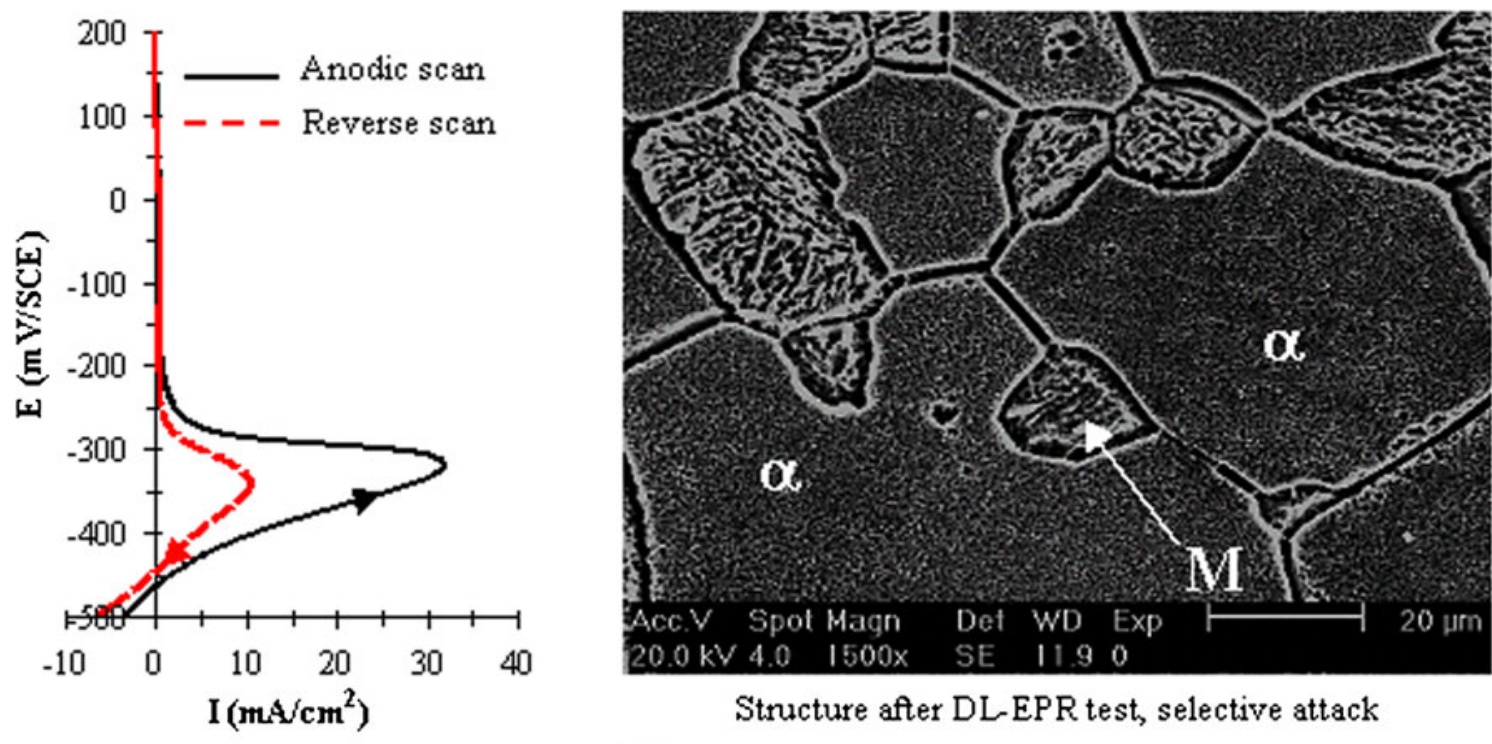

Structure after DL-EPR test, selective attack

(a)


Structure after DL-EPR test, uniform attack of $\alpha$ phase and dissolution of martensite islets.

(b)

Fig. 10-Effect of the potential scanning rate on the DL-EPR test selectivity. (a) Steel aged at $873 \mathrm{~K}\left(600{ }^{\circ} \mathrm{C}\right)$ for $2 \mathrm{~h}$, test carried out with a $3 \mathrm{M}$ solution of $\mathrm{H}_{2} \mathrm{SO}_{4}$ under $d E / d t=2.5 \mathrm{mV} / \mathrm{s}$ and at the temperature of $293 \mathrm{~K}\left(20^{\circ} \mathrm{C}\right)$. (b) Steel aged at $873 \mathrm{~K}\left(600{ }^{\circ} \mathrm{C}\right)$ for $2 \mathrm{~h}$, test carried out with a $3 \mathrm{M}$ solution of $\mathrm{H}_{2} \mathrm{SO}_{4}$ under $d E / d t=0.5 \mathrm{mV} / \mathrm{s}$ and at the temperature of $293 \mathrm{~K}\left(20^{\circ} \mathrm{C}\right)$. 
reactivation current is equal to zero $\left(I_{r}=0\right)$ for low sensitized state without attack.

(2) Range of intermediate rates $(1<d E / d t \leq 2.5 \mathrm{mV} / \mathrm{s})$ : The test conserves the attack selectivity and sensitivity concerning the detection of the effect of low dechromizations (Figure 10(a)). In this range, good compatibility between the kinetics of electrochemical reactions and those of potential scanning rates is put in evidence.

(3) Range of low rates $(d E / d t \leq 1 \mathrm{mV} / \mathrm{s})$ : The DL-EPR test was not able to detect the presence of chromium-depleted areas, since $I_{r} / I_{a}$ ratios exceed the sensitization criterion (1 pct) for the solutionannealed steel, which is supposed to be not sensitized. Moreover, under these conditions of very slow potential scanning, the surface reactivity $\left(I_{r}\right)$ is sufficiently high in the $\mathrm{H}_{2} \mathrm{SO}_{4}$ electrolyte to induce uniform attack of the $\alpha$ phase with an orange skin morphology and dissolution of the martensite islets (Figure 10(b)).

Accordingly, it can be stated that the rate of $d E / d t=$ $2.5 \mathrm{mV} / \mathrm{s}$ is the most compatible with the kinetics of electrochemical reactions involved, in chromiumdepleted areas. Therefore, this value will be retained for controlling the degree of sensitization to the IGC of ferritic stainless steels by the DL-EPR tests.

\section{Effect of depassivator concentration $\left(\mathrm{NH}_{4} \mathrm{SCN}\right)$}

Results of the experimental design reported in Table II show that the $I_{r} / I_{a}$ (pct) ratios, corresponding to the solution-annealed steel that is supposed to be not sensitized, exceed 1 pct with the addition of the $\mathrm{NH}_{4} \mathrm{SCN}$ depassivator even with concentrations as low as $0.01 \mathrm{~mol} / \mathrm{L}$. These ratios are incompatible with the excessive attacks revealed at grain boundaries without

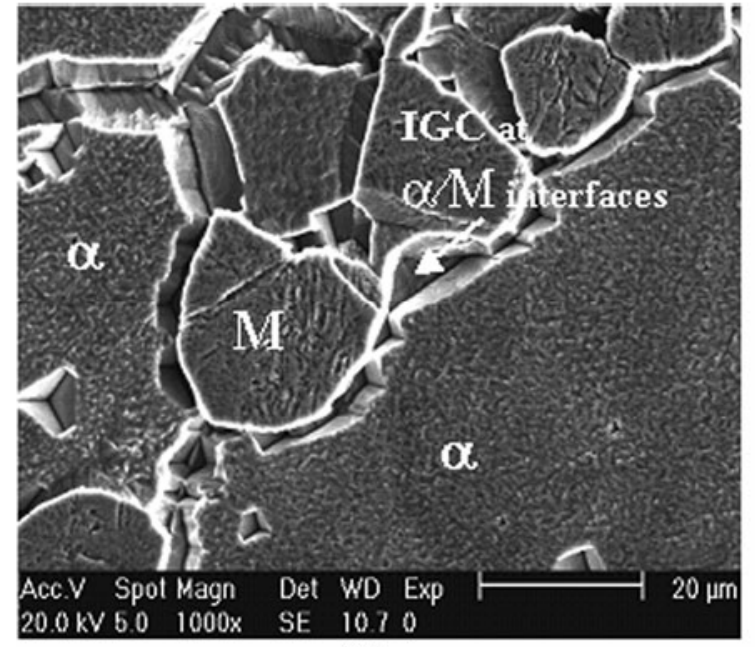

(a)

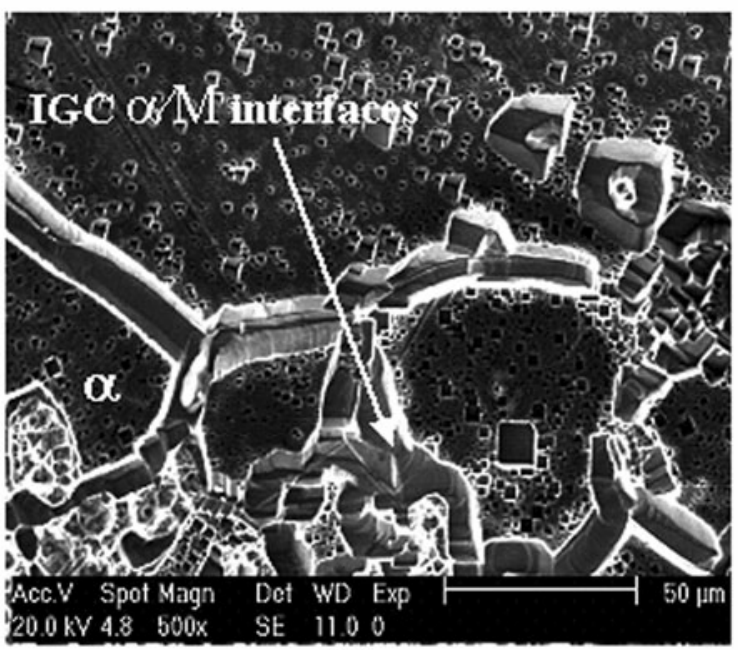

(b)

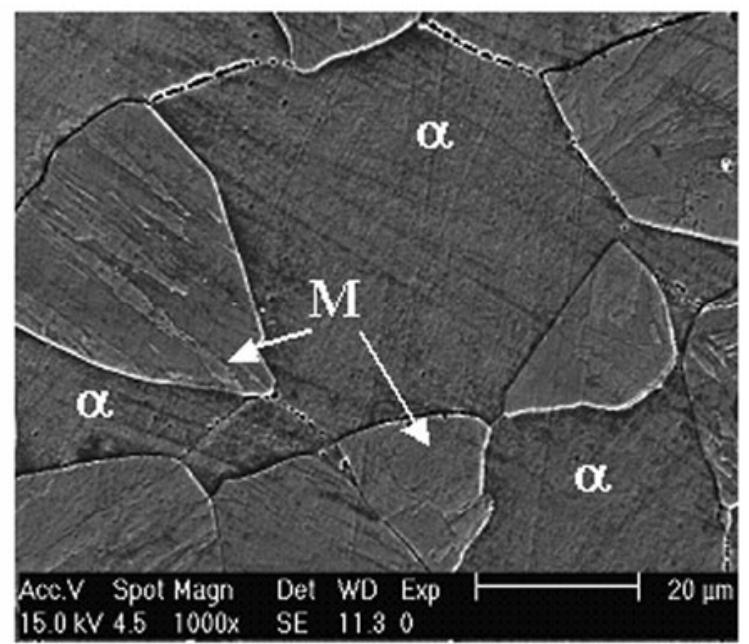

(c)

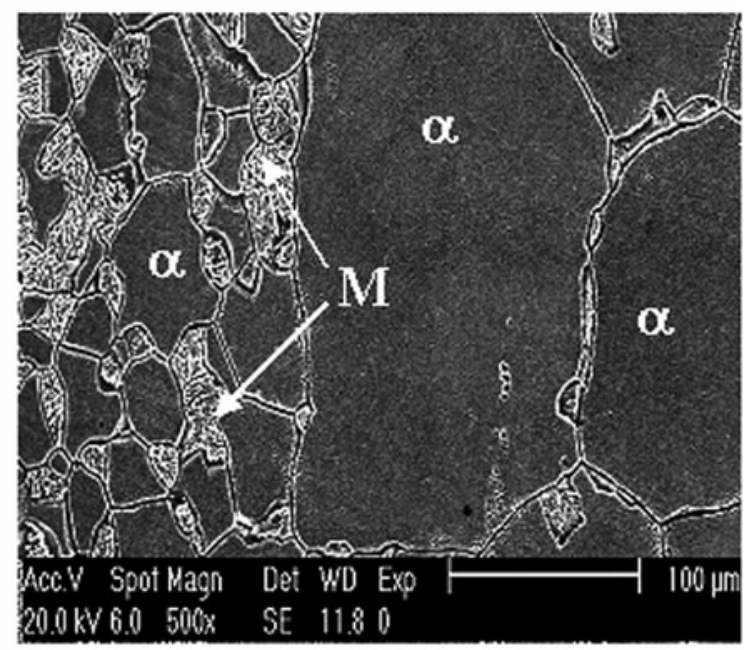

(d)

Fig. 11-Influence of the depassivator concentration on the selectivity of the DL-EPR test performed under $2.5 \mathrm{mV} / \mathrm{s}$ and at $293 \mathrm{~K}\left(20^{\circ} \mathrm{C}\right)$. (a) Structure after DL-EPR test, non selective attack. Test with: $\mathrm{H}_{2} \mathrm{SO}_{4} 0.1 \mathrm{M}+\mathrm{NH}_{4} \mathrm{SCN} 0.01 \mathrm{M}$ solution annealed steel (non sensitized). (b) Structure after DL-EPR test, uniform attack. Test with: $\mathrm{H}_{2} \mathrm{SO}_{4} 0.1 \mathrm{M}+\mathrm{NH}_{4} \mathrm{SCN} 0.01 \mathrm{M}$ steel aged at $873 \mathrm{~K}\left(600{ }^{\circ} \mathrm{C}\right)$ for $2 \mathrm{~h}($ highly sensitized). (c) Structure after DL-EPR test, selective attack. Test with: $\mathrm{H}_{2} \mathrm{SO}_{4} 3 \mathrm{M}$ solution annealed steel (non sensitized). (d) Structure after DL-EPR test, selective attack. Test with: $\mathrm{H}_{2} \mathrm{SO}_{4} 3 \mathrm{M}$ steel aged at $873 \mathrm{~K}\left(600{ }^{\circ} \mathrm{C}\right)$ for $2 \mathrm{~h}$ (highly sensitized). 


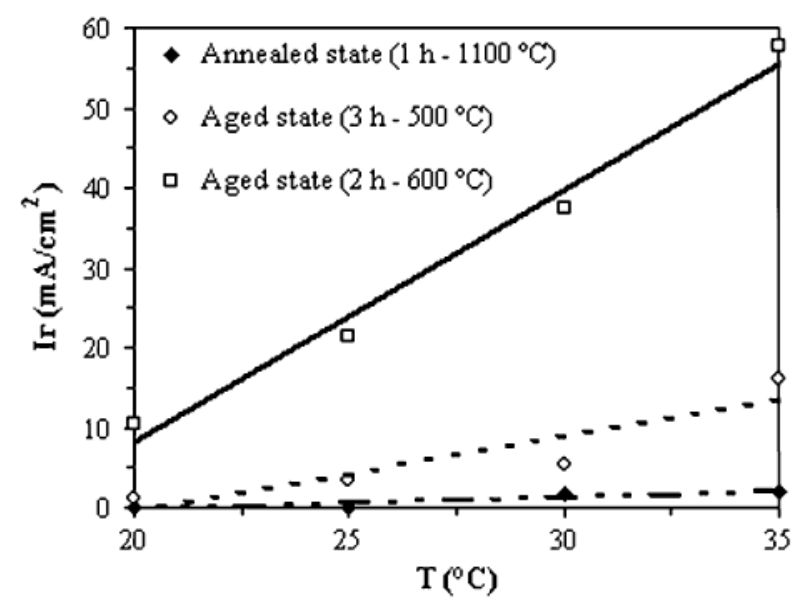

(a)

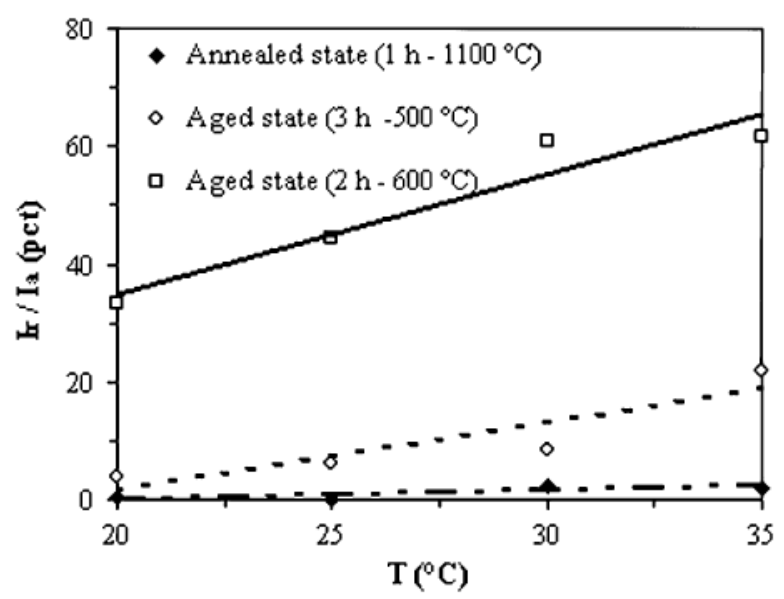

(b)

Fig. 12-Influence of the electrolyte temperature on the repassivation kinetics and the DL-EPR test response $\left(I_{r} / I_{a}\right.$ pct); test carried out with a $3 \mathrm{M}$ solution of $\mathrm{H}_{2} \mathrm{SO}_{4}$ and a potential scanning rate of $2.5 \mathrm{mV} / \mathrm{s}$. (a) Effect of the electrolyte temperature on the repassivation kinetics $\left(I_{r}\right.$ in $\left.\mathrm{mA} / \mathrm{cm}^{2}\right)$. (b) Effect of the electrolyte temperature on the DL-EPR test response $\left(I_{r} / l_{a}\right.$ pct).

precipitation (Figure 11(a)). The same results are obtained for steel aged during 2 hours at $873 \mathrm{~K}$ $\left(600^{\circ} \mathrm{C}\right)$. In this case, the attack appears uniform with corrosion pit distribution (Figure 11(b)). In both cases, the selectivity of the attack was found in the electrolyte without the depassivator (Figures 11(c) and (d)). Accordingly, the depassivator is not recommended for controlling the degree of sensitization to the IGC of ferritic stainless steels by the DL-EPR method.

\section{Effect of electrolyte temperature}

The density of the current $\left(I_{r}\right)$ and the current ratio $\left(I_{r} / I_{a}\right)$ of the DL-EPR test, performed in $\mathrm{H}_{2} \mathrm{SO}_{4}$ electrolyte $(3 \mathrm{M})$ without depassivator and at a potential scanning rate of $d E / d t=2.5 \mathrm{mV} / \mathrm{s}$, are not significantly affected by temperature variation between $293 \mathrm{~K}$ and $308 \mathrm{~K}\left(20^{\circ} \mathrm{C}\right.$ and $\left.35^{\circ} \mathrm{C}\right)$ for the solution-annealed state (Figures 12(a) and (b)). However, the test response has changed significantly with increasing temperature for aged states, and the selectivity of the attack decreases in accordance with the $I_{r} / I_{a}$ ratio. Indeed, from $303 \mathrm{~K}$ $\left(30^{\circ} \mathrm{C}\right)$, the solution becomes sufficiently aggressive (decreased $\mathrm{pH}$ ) to cause a uniform attack confirmed by the simultaneous increase of the reactivation current and an almost total dissolution of martensitic islets for aged states (Figure 13). Accordingly, maintaining the electrolyte temperature at $293 \mathrm{~K}\left(20^{\circ} \mathrm{C}\right)$ is recommended for controlling the degree of sensitization to the IGC of ferritic stainless steels by the DL-EPR test (Figure 13(a)).

\section{Optimal conditions of the DL-EPR test}

The ratios of current densities $\left(I_{r} / I_{a} \mathrm{pct}\right)$ deducted by the DL-EPR test, performed on the solution-annealed state (nonsensitized) and states aged during 3 hours at $773 \mathrm{~K}\left(500^{\circ} \mathrm{C}\right)$ (low sensitized) and during 2 hours at $873 \mathrm{~K}\left(600^{\circ} \mathrm{C}\right)$ (highly sensitized), under optimal conditions are reported in Table IV. Under these conditions, the sensitivity of the DL-EPR test to detect the effect of low dechromization with good reproducibility and to conserve the attack selectivity are demonstrated for the UNS S43000 ferritic stainless steel.

\section{Quantitative Assessment of Sensitization to the IGC}

The optimal operating conditions of the DL-EPR test are used to assess the degree of sensitization to the IGC of the studied steel aged at temperatures ranging from $673 \mathrm{~K}$ to $1123 \mathrm{~K}\left(400{ }^{\circ} \mathrm{C}\right.$ to $\left.850{ }^{\circ} \mathrm{C}\right)$. The $I_{r} / I_{a}$ (pct) ratios and the resulting microstructures after the DL-EPR tests are reported in Table V. These ratios led to establishment of the TTS diagram for the UNS S43000 ferritic stainless steel. The DOS, expressed by the values of the $\left(I_{r} / I_{a} \mathrm{pct}\right)$ ratio, appear in good agreement with the TTP diagram derived from microstructural observations (Figure 14).

\section{DISCUSSION}

\section{A. Optimization of Operating Conditions of the DL-EPR Test}

Results of this study show that, in the same way as for austenitic ${ }^{[9]}$ and duplex stainless steels,${ }^{[8]}$ the sensitivity of the DL-EPR test to detect the effect of low dechromization depends strongly on the operating conditions. It was shown also that the quantitative assessment of the DOS to the IGC, on the basis of the reactivation and anodic current ratio $\left(I_{r} / I_{a}\right.$ pct $)$ values, requires selectivity of the attack that depends itself on the test operating conditions. In fact, the current ratio should reflect the responses of the chromium-depleted areas only (intercrystalline corrosion) during the potential scanning. In addition, taking into account the criteria of sensitivity and selectivity of the test, established by the ANOVA method, reveals the significant effects of various operating factors. This leads to the selection of optimal operating conditions for quantitative and reproducible control of the ferritic stainless steel IGC sensitization. The comparison given in Table VI of the results of DOS of tested specimens under the optimal operating 

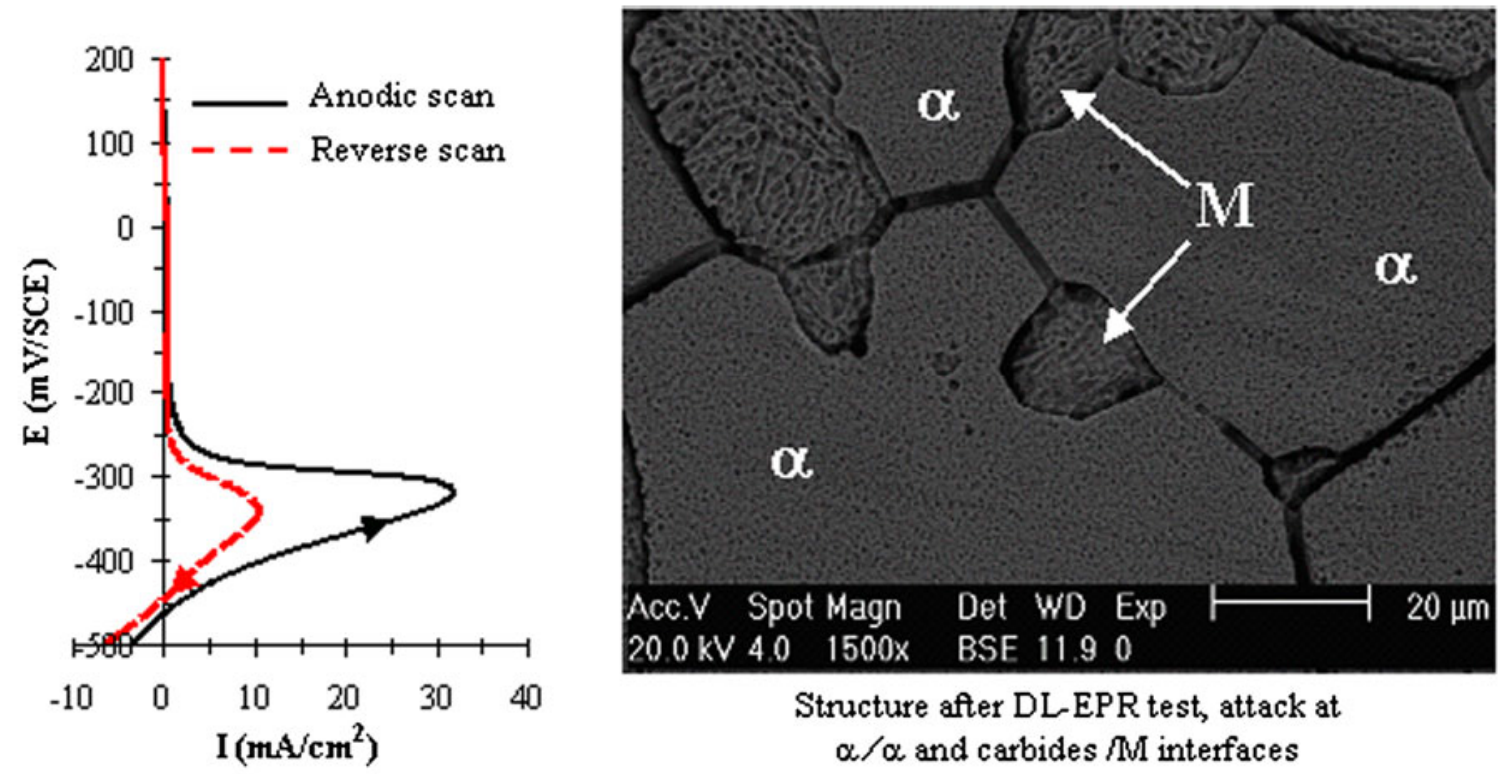

Structure after DLEPR test, attack at $\alpha / \alpha$ and carbides $M$ interfaces

(a)
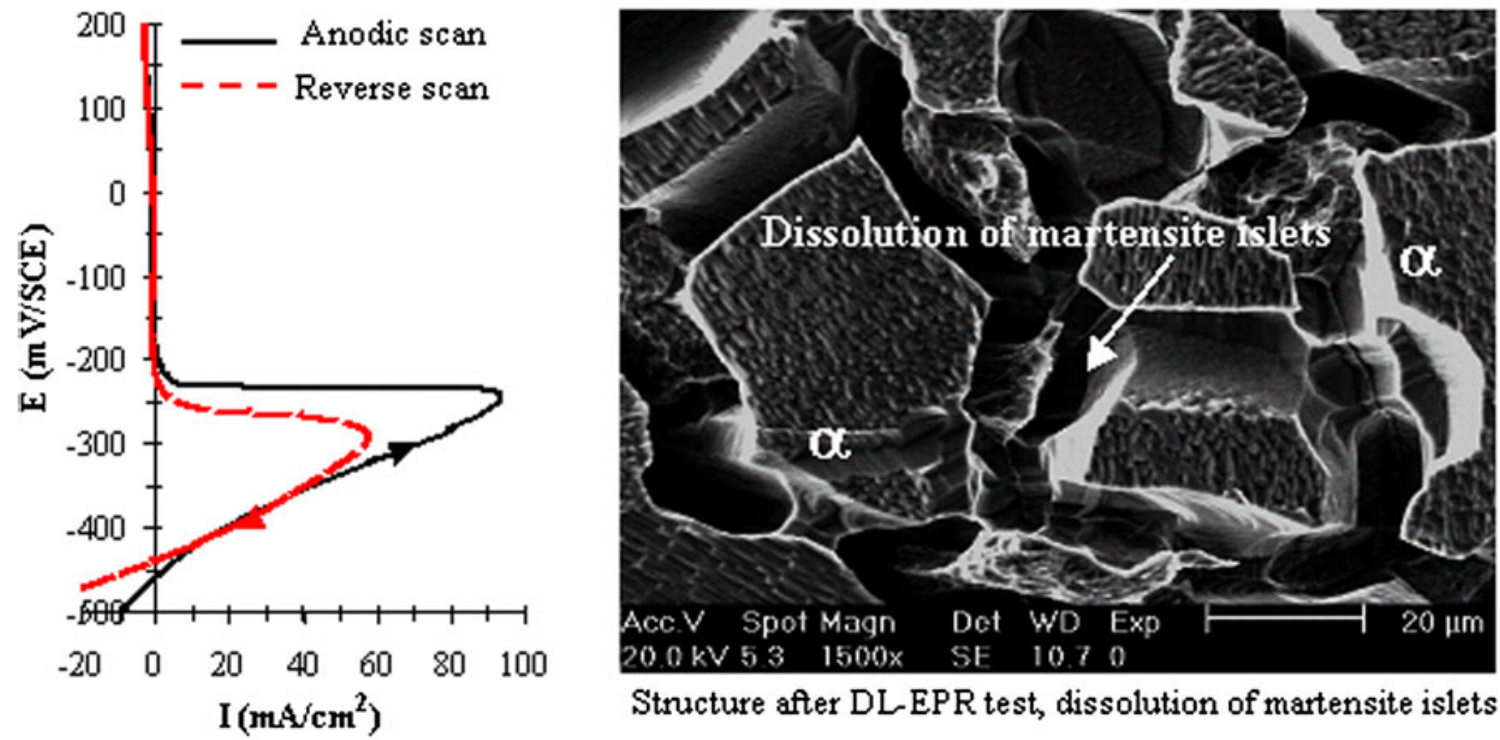

Structure after DLEPR test, dissolution of martensite islets

(b)

Fig. 13-Effect of the electrolyte temperature on the DL-EPR test selectivity. (a) Steel aged at $873 \mathrm{~K}\left(600{ }^{\circ} \mathrm{C}\right)$ for $2 \mathrm{~h}$, test carried out with a $3 \mathrm{M}$ solution of $\mathrm{H}_{2} \mathrm{SO}_{4}$ under $d E / d t=2.5 \mathrm{mV} / \mathrm{s}$ and at the temperature of $293 \mathrm{~K}\left(20^{\circ} \mathrm{C}\right)$. (b) Steel aged at $873 \mathrm{~K}\left(600^{\circ} \mathrm{C}\right)$ for $2 \mathrm{~h}$, test carried out with a $3 \mathrm{M}$ solution of $\mathrm{H}_{2} \mathrm{SO}_{4}$ under $d E / d t=2.5 \mathrm{mV} / \mathrm{s}$ and at the temperature of $308 \mathrm{~K}\left(35^{\circ} \mathrm{C}\right)$.

conditions, with results of DL-EPR tests conducted using the operating conditions cited by the literature, ${ }^{[2,7]}$ highlights the following comments.

(1) By using the Dowling operating conditions, ${ }^{[7]}$ the $I_{r} / I_{a}$ ratios obtained for the solution-annealed state are abnormally high $\left(I_{r} / I_{a}=52 \mathrm{pct}\right)$ : according to the microstructure, this state is not sensitized. In addition, the $I_{r} / I_{a}$ ratio, evaluated for the aged specimen during 3 hours at $773 \mathrm{~K}\left(500^{\circ} \mathrm{C}\right)$, is quite low $\left(I_{r} / I_{a}=39 \mathrm{pct}\right)$ : according to the microstructure, the steel is supposed to be low sensitized in this case. Therefore, the value of the $I_{r} / I_{a}$ ratio is expected to be much higher than the value measured for the solution-annealed state. Under these operating conditions, it was verified that the high values of the reactivation current are the result of uniform attack. Accordingly, the selectivity of the test conducted under these conditions is not respected.

(2) When the operating conditions selected by Lee ${ }^{[2]}$ were used, the solution-annealed state is found to be not sensitized $\left(I_{r} / I_{a}<1 \mathrm{pct}\right)$, as revealed by the microstructure examinations. However, the values of $I_{r} / I_{a}$ measured for the low sensitized state $\left(I_{r} / I_{a}=5.5 \mathrm{pct}\right)$, corresponding to an aging duration of 3 hours at $773 \mathrm{~K}\left(500^{\circ} \mathrm{C}\right)$, and the highly 
Table IV. Optimal Conditions for Evaluation by DL-EPR Testing of the IGC Sensitization of the UNS S43000

\begin{tabular}{|c|c|c|c|c|c|c|}
\hline & & & & \multirow{2}{*}{$\begin{array}{c}\text { Nonsensitized State } \\
\text { WSA: } 1 \mathrm{~h} \\
\text { at } 1373 \mathrm{~K}\left(1100{ }^{\circ} \mathrm{C}\right) \\
\text { and Water Cooling }\end{array}$} & \multicolumn{2}{|c|}{ Sensitized State } \\
\hline \multicolumn{4}{|c|}{ Operating Conditions } & & $\begin{array}{l}\text { WSA + Aging } \\
\text { for } 3 \mathrm{~h} \text { at } 773 \mathrm{~K} \\
\left(500^{\circ} \mathrm{C}\right)\end{array}$ & $\begin{array}{l}\text { WSA + Aging } \\
\text { for } 2 \mathrm{~h} \text { at } 873 \mathrm{~K} \\
\left(600^{\circ} \mathrm{C}\right) \text { and }\end{array}$ \\
\hline Electrolyte & $T \mathrm{~K}\left({ }^{\circ} \mathrm{C}\right)$ & $d E / d t(\mathrm{mV} / \mathrm{s})$ & $\begin{array}{l}\text { Range of Potential } \\
\text { Scanning (mV/ECS) }\end{array}$ & $I_{r} / I_{a}(\mathrm{Pct})$ & $I_{r} / I_{a}(\mathrm{Pct})$ & $I_{r} / I_{a}(\mathrm{Pct})$ \\
\hline $\mathrm{H}_{2} \mathrm{SO}_{4} 3 \mathrm{M}$ & $293(20)$ & 2.5 & $-500 \leftrightarrow 200$ & 0.30 & 2.61 & 33.14 \\
\hline
\end{tabular}

Table V. Assessing the Degree of Sensitization to the IGC of the UNS S43000 Stainless Steel by the DL-EPR Test Performed in the Optimal Operating Conditions

\begin{tabular}{|c|c|c|c|c|c|c|c|}
\hline & \multicolumn{3}{|c|}{ Heat Treatment } & \multicolumn{2}{|c|}{ Microstructural Analysis } & \multicolumn{2}{|c|}{ IGC Sensitization } \\
\hline & $\begin{array}{c}\text { Temperature } \\
\mathrm{K}\left({ }^{\circ} \mathrm{C}\right)\end{array}$ & $\begin{array}{l}\text { Duration } \\
\text { (Min) }\end{array}$ & $\begin{array}{c}\text { Cooling } \\
\text { Conditions }\end{array}$ & $\begin{array}{c}\text { Interfaces, } \\
\alpha / \alpha\end{array}$ & $\begin{array}{c}\text { Interfaces } \\
\text { Carbides, M }\end{array}$ & $I_{r} / I_{a}(\mathrm{Pct})$ & $Q_{r} / Q_{a}(\mathrm{Pct})$ \\
\hline WSA & $1373(1100)$ & 60 & water & step & step & 0.30 & 0.14 \\
\hline ASA & $1373(1100)$ & 60 & air & dual & ditch & 10.25 & 10.98 \\
\hline \multirow{26}{*}{$\begin{array}{l}\text { Aging } \\
\text { (after WSA) }\end{array}$} & $673(400)$ & 30 & air & step & step & 0 & 0 \\
\hline & & 60 & & step & step & 0.63 & 0.53 \\
\hline & & 120 & & step & step & 0 & 0 \\
\hline & $723(450)$ & 30 & & dual & dual & 1.04 & 0.51 \\
\hline & & 60 & & dual & dual & 1.28 & 0.78 \\
\hline & $773(500)$ & 5 & & dual & dual & 4.8 & 3.53 \\
\hline & & 10 & & dual & ditch & 10.10 & 9.6 \\
\hline & & 60 & & dual & ditch & 10.12 & 11.37 \\
\hline & & 120 & & dual & ditch & 13.69 & 7.97 \\
\hline & & 180 & & step & dual & 2.61 & 2.39 \\
\hline & $823(550)$ & 5 & & dual & ditch & 16.50 & 18.64 \\
\hline & $873(600)$ & 5 & & dual & ditch & 18.05 & 19.4 \\
\hline & & 15 & & dual & ditch & 18.22 & 20.52 \\
\hline & & 120 & & dual & ditch & 33.14 & 32.44 \\
\hline & & 240 & & dual & ditch & 13.26 & 12.78 \\
\hline & & 480 & & dual & dual & 3.75 & 1.67 \\
\hline & $973(700)$ & 5 & & dual & ditch & 16.38 & 12.81 \\
\hline & & 60 & & dual & dual & 1.75 & 1.59 \\
\hline & & 180 & & dual & dual & 1.85 & 2.64 \\
\hline & $1073(800)$ & 5 & & dual & dual & 2.06 & 2.46 \\
\hline & & 30 & & step & step & 0.42 & 0.31 \\
\hline & & 60 & & step & step & 0.02 & 0 \\
\hline & & 120 & & step & step & 0 & 0 \\
\hline & $1123(850)$ & 5 & & step & step & 0 & 0 \\
\hline & & 30 & & step & step & 0 & 0 \\
\hline & & 60 & & step & step & 0 & 0 \\
\hline
\end{tabular}

ASA: air solution annealed; WSA: water solution annealed; $\alpha$ : ferrite; M: martensite; step: no intercrystalline attack; dual: slight intercrystalline attack; and ditch: high intercrystalline attack.

sensitized state $\left(I_{r} / I_{a}=7.5 \mathrm{pct}\right)$, corresponding to an aging duration of 2 hours at $873 \mathrm{~K}\left(600^{\circ} \mathrm{C}\right)$, are very close. This result does not conform to the obvious microstructure differences of the aged states. This test defect is due to the fact that the kinetics of potential scanning $(d E / d t=4.17 \mathrm{mV} / \mathrm{s})$ are much faster than the kinetics of the repassivation of chromium-depleted areas. This explanation is supported by the low values of the reactivation current $\left(I_{r}=3\right.$ to $\left.3.2 \mathrm{~mA} / \mathrm{cm}^{2}\right)$.
(3) Concerning the optimal operating conditions established in this study $\left(\mathrm{H}_{2} \mathrm{SO}_{4} 3 \mathrm{M}, d E / d t=2.5 \mathrm{mV} / \mathrm{s}\right.$, and $T=293 \mathrm{~K}\left(20^{\circ} \mathrm{C}\right)$ without depassivator), the sensitivity and selectivity of the test are satisfactory. Indeed, nonsensitization of the solution-annealed state is confirmed $\left(I_{r} / I_{a}=0.3 \mathrm{pct}\right)$. Additionally, sensitization to the IGC of aged states is well marked, with a value of $I_{r} / I_{a}=2.6$ pct for the low sensitized state and a value of $I_{r} / I_{a}=33$ pct for the highly sensitized state. Good results are also 


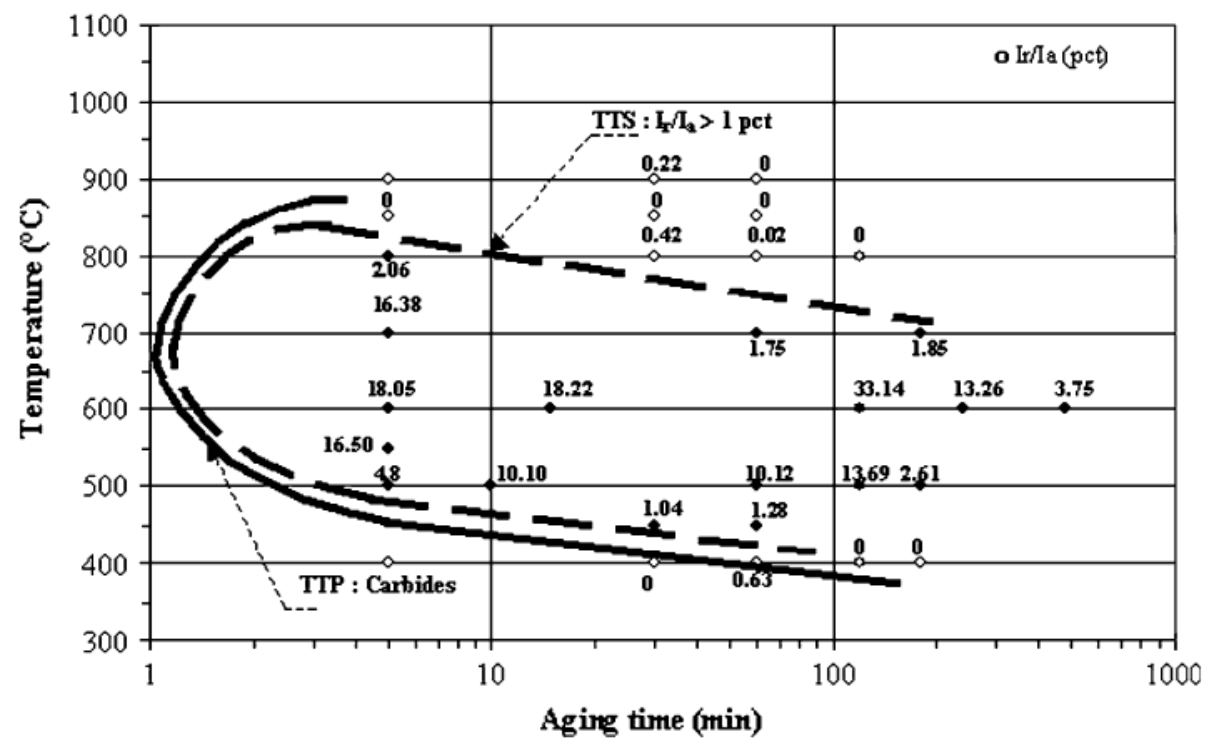

Fig. 14-Interaction precipitation-IGC sensitization of the ferritic stainless steel grade UNS S43000.

Table VI. Comparison of Operating Conditions of the DL-EPR Testing

\begin{tabular}{|c|c|c|c|c|}
\hline Heat Treatment & $\begin{array}{c}\text { Quantitative } \\
\text { Evaluation of } \\
\text { IGC Sensitization } \\
\text { by the DL-EPR Test }\end{array}$ & $\begin{array}{c}\text { Dowling et al. } .^{[7]} \\
\mathrm{H}_{2} \mathrm{SO}_{4} 2 \mathrm{M}+\mathrm{NaCl} 0.5 \mathrm{M} \\
+\mathrm{KSCN} 0.01 \mathrm{M} \\
T=293 \mathrm{~K}\left(20^{\circ} \mathrm{C}\right) \\
d E / d t=2.5 \mathrm{mV} / \mathrm{s}\end{array}$ & $\begin{array}{c}\text { Lee }^{[2]} \\
\mathrm{H}_{2} \mathrm{SO}_{4} 3 \mathrm{~N} ; \\
T=303 \mathrm{~K}\left(30^{\circ} \mathrm{C}\right) ; \\
d E / d t=4.17 \mathrm{mV} / \mathrm{s}\end{array}$ & $\begin{array}{c}\text { This Study } \\
\mathrm{H}_{2} \mathrm{SO}_{4} 3 \mathrm{M} ; \\
T=293 \mathrm{~K}\left(20^{\circ} \mathrm{C}\right) ; \\
d E / d t=2.5 \mathrm{mV} / \mathrm{s}\end{array}$ \\
\hline Solution annealing & $I_{r}\left(\mathrm{~mA} / \mathrm{cm}^{2}\right)$ & 154.8 & $<0$ & 0.1 \\
\hline $\begin{array}{l}1373 \mathrm{~K}\left(1100^{\circ} \mathrm{C}\right)-1 \mathrm{~h}- \\
\text { water cooling }\end{array}$ & $I_{r} / I_{a}(\mathrm{pct})$ & 52.1 & 0 & 0.3 \\
\hline Aging $773 \mathrm{~K}\left(500^{\circ} \mathrm{C}\right)-$ & $I_{r}\left(\mathrm{~mA} / \mathrm{cm}^{2}\right)$ & 142.4 & 3 & 1 \\
\hline $3 \mathrm{~h}$-air cooling & $I_{r} / I_{a}(\mathrm{pct})$ & 39 & 5.5 & 2.6 \\
\hline Aging $873 \mathrm{~K}\left(600^{\circ} \mathrm{C}\right)-$ & $I_{r}\left(\mathrm{~mA} / \mathrm{cm}^{2}\right)$ & 201 & 3.2 & 10.6 \\
\hline 2 h-air cooling & $I_{r} / I_{a}(\mathrm{pct})$ & 70 & 7.5 & 33.1 \\
\hline
\end{tabular}

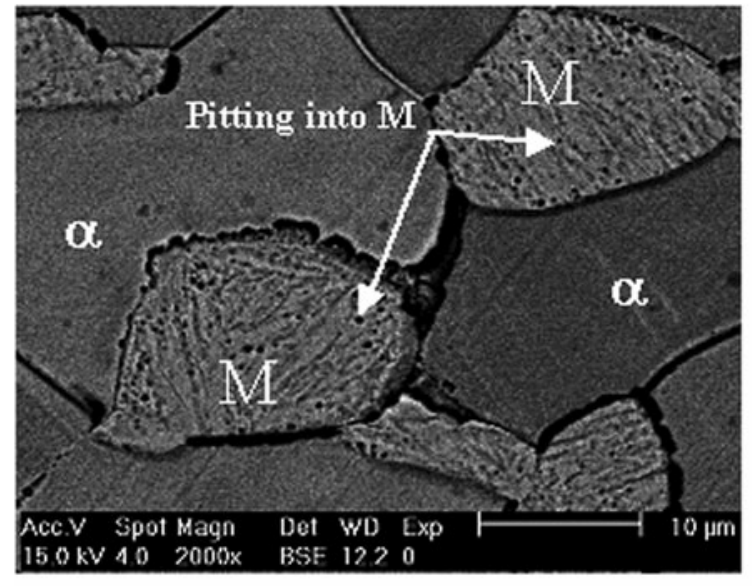

(a)

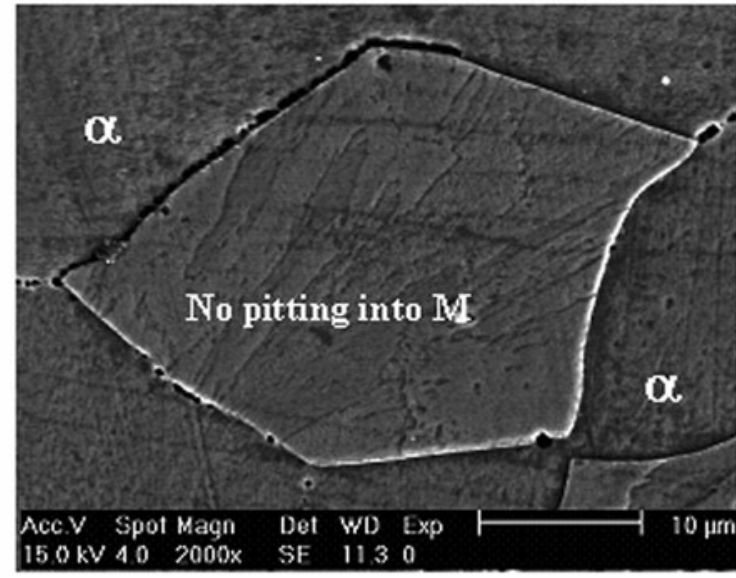

(b)

Fig. 15-Effect of the cooling rate on the selectivity of the attack after DL-EPR testing under $2.5 \mathrm{mV} / \mathrm{s}$ and at $293 \mathrm{~K}\left(20^{\circ} \mathrm{C}\right)$. (a) Structure after DL-EPR test, $\mathrm{H}_{2} \mathrm{SO}_{4} 3 \mathrm{M}$ (uniform attack). Solution annealed steel, air cooling. (b) Structure after DL-EPR test, $\mathrm{H}_{2} \mathrm{SO}_{4} 3 \mathrm{M}$ (selective attack). Solution annealed steel, water cooling.

observed for the attack selectivity of the chromiumdepleted areas. This selectivity may be affected when the potential scanning rate decreases
$(<2.5 \mathrm{mV} / \mathrm{s})$, or when the severity of the electrolyte increases $(>3 \mathrm{M})$ or when its temperature is high $\left(>303 \mathrm{~K}\left(30^{\circ} \mathrm{C}\right)\right)$. Similarly, the selectivity of the 
attack cannot be guaranteed in the presence of a depassivator even with very low concentrations.

\section{B. Effect of Solution Annealing and Aging Conditions on the IGC Resistance of the UNS S43000 Ferritic Stainless Steel}

\section{Effect of solution-annealing conditions}

The difference in IGC sensitization was clearly observed between the two solution-annealed conditions (water and air cooling) by the DL-EPR test. The test detects a sensitization to the IGC for solution annealing and air cooling $\left(I_{r} / I_{a}=10.25 \mathrm{pct}\right)$ compared to solution annealing and water cooling $\left(I_{r} / I_{a}=0.3 \mathrm{pct}\right)$. This sensitization is attributed to low dechromization following a precipitation of chromium carbides, at the temperature range from $773 \mathrm{~K}$ to $1123 \mathrm{~K}\left(500{ }^{\circ} \mathrm{C}\right.$ to $\left.850{ }^{\circ} \mathrm{C}\right)$, in the aggregates of carbon oversaturated martensite (M), and likely a small amount of residual austenite $\left(\gamma_{\text {res }}\right)$, during air cooling. Fine attacks, highlighted in the martensitic islets by metallographic observation, confirm this state of sensitization (Figure 15(a)). However, water cooling was sufficiently fast to prevent any precipitation and consecutive dechromization. This result is confirmed by the absence of any form of attack or selective dissolution after the DL-EPR test conducted on the water-solution-annealed steel (Figure 15(b)).

\section{Effect of aging conditions}

The superimposition of TTP and TTS diagrams puts in evidence the existence of significant interactions between precipitation-sensitization-desensitization in the IGC of the UNS S43000 ferritic stainless steel under various temperatures and durations due to its microstructural instability. It appears that the oversaturation of martensite by carbon and the fast diffusion of chromium in this phase control the dechromization mechanism and the rehomogenization phenomenon. The dechromization is mainly located in the martensitic islets, which may take place during heating at temperatures ranging from $773 \mathrm{~K}$ to $1123 \mathrm{~K}\left(500{ }^{\circ} \mathrm{C}\right.$ to $\left.850{ }^{\circ} \mathrm{C}\right)$. Indeed, at temperatures below $773 \mathrm{~K}\left(500{ }^{\circ} \mathrm{C}\right)$, the chromium diffusion kinetics is relatively slow, so it prevents the rehomogenization of the chromium-depleted zones created during the decomposition of martensite into chromium-depleted ferrite and chromium carbides. Therefore, the sensitization can start after aging for at least 3 hours duration at $773 \mathrm{~K}$ $\left(500^{\circ} \mathrm{C}\right)$. This duration coincides with the onset of martensite decomposition. However, aging at $873 \mathrm{~K}$ $\left(600{ }^{\circ} \mathrm{C}\right)$ leads to a sensitization that occurs rapidly followed by desensitization after 8 hours when the depleted zones restore the critical chromium content (self healing) that is greater than or equal to 13 pct. $^{[29]}$ At higher temperatures $\left(>973 \mathrm{~K}\left(700^{\circ} \mathrm{C}\right)\right)$, chromium diffusion is very fast and leads to the rehomogenization of the depleted zones, and the phenomenon of sensitization to the IGC is avoided.

\section{CONCLUSIONS}

It was verified that electrochemical DL-EPR tests, conducted in the $\mathrm{H}_{2} \mathrm{SO}_{4} 3 \mathrm{M}$ electrolyte without depassivator at temperature of $293 \mathrm{~K}\left(20^{\circ} \mathrm{C}\right)$ with a potential scanning from -500 to $+200 \mathrm{mV} / \mathrm{ECS}$ at a rate of $2.5 \mathrm{mV} / \mathrm{s}$, can be used as a reliable nondestructive technique for quantitative assessment of ferritic stainless steel DOS. Using the criterion of $I_{r} / I_{a}>1 \mathrm{pct}$, the TTS diagram of the UNS S43000 ferritic stainless steel grade was plotted. It shows a good agreement with the results of microstructural evolution that occur during the aging at temperatures ranging from $673 \mathrm{~K}$ to $1123 \mathrm{~K}\left(400^{\circ} \mathrm{C}\right.$ to $\left.850^{\circ} \mathrm{C}\right)$.

\section{REFERENCES}

1. B. Baroux: Les Aciers Inoxydables, Editions de Physique, 1990, pp. $519-49$.

2. J.B. Lee: Corrosion-Nace, 1986, vol. 42 (2), pp. 106-10.

3. S. Frangini and A. Mignone: Corrosion, 1992, vol. 48 (9), pp. $715-$ 26.

4. M. Colombie, A. Condylis, A. Desestret, R. Grand, and R. Mayoud: Rev. Metall. (Paris) Pt. 1, 1973, vol. 70, p. 949.

5. NF EN ISO 3651-2, AFNOR, France, 1998.

6. NF EN ISO 3651-1, AFNOR, France, 1998.

7. N.J.E. Dowling, H. Kim, J.-N. Kim, S.-K. Ahn, and Y.-D. Lee: Corrosion, 1992, vol. 55 (8), pp. 743-55.

8. T. Amadou, C. Braham, and H. Sidhom: Metall. Mater. Trans. A, 2004, vol. 35A, pp. 3499-3513.

9. H. Sidhom, T. Amadou, H. Sahlaoui, and C. Braham: Metall. Mater. Trans. A, 2007, vol. 38A, pp. 1269-80.

10. F. Mazaudier, G. Sanchez, and P. Fauvet: 3rd Eur. Conf. on Corrosion, Proc. Conf., CEFRACOR, Lyon, France, 1997, pp. p12-1-p12-6.

11. P. Záhumenský, S. Tuleja, J. Országová, J. Janovec, and V. Siládiová: Corros. Sci., 1999, vol. 41, pp. 1305-22.

12. Y.J. Oh, J.H. Yoon, and J.H. Hong: Corrosion, 2000, vol. 56 (3), pp. $289-97$.

13. S.J. Goodwin, B. Quayle, and F.W. Noble: Corros.-Nace, 1987, vol. 43 (12), pp. 743-47.

14. Z. Fang, Y.S. Wu, L. Zhang, and J.Q. Li: Corrosion, 1998, vol. 54 (5), pp. $339-46$.

15. U. Kamachi Mudali, R.K. Dayal, J.B. Gnanamoorthy, and P. Rodriguez: Metall. Mater. Trans. A, 1996, vol. 27A, pp. 2881-87.

16. M. Verneau and B. Bonnefois: 3rd Eur. Conf. on Corrosion, Proc. Conf., CEFRACOR, Lyon, France, 1997, pp. C5-1-C5-6.

17. Y. Jun Oh and J. Hwa Hong: J. Nucl. Mater., 2000, vol. 278, pp. 242-50.

18. D.N. Wasnik, V. Kain, I. Samajdar, B. Verlinden, and P.K. De: Acta Mater., 2002, vol. 50, pp. 4587-4601.

19. Y. Cetre, P. Eichner, G. Sibaud, and J.M. Scarabello: 3rd Eur. Conf. on Corrosion, Proc. Conf., CEFRACOR, Lyon, France, 1997, pp. C4-1-C4-12.

20. A.P. Majidi and M.A. Streicher: Corros.-Nace, 1984, vol. 40 (11), pp. 58493.

21. C.C. Silva, J.P.S.E. Machado, A.V.C. Sobral-Santiago, H.B. de Sant'Ana, and J.P. Farias: J. Petrol. Sci. Eng., 2007, vol. 59, pp. $219-25$.

22. T. Luz, J.P. Farias, and P. Neto: Weld. Int., 2006, vol. 20 (12), pp. 959-64.

23. A. Pardo, M.C. Merino, A.E. Coy, F. Viejo, M. Carboneras, and R. Arrabal: Acta Mater., 2007, vol. 55, pp. 2239-51.

24. V.S. Moura, L.D. Lima, J.M. Pardal, A.Y. Kina, R.R.A. Corte, and S.S.M. Tavares: Mater. Characterization, 2008, vol. 59, pp. 1127-32.

25. A.Y. Kina, V.M. Souza, S.S.M. Tavares, J.A. Souza, and H.F.G. de Abreu: J. Mater. Process. Technol., 2008, vol. 199, pp. 391-95.

26. S.S.M. Tavares, J.S. Corte, C.A.B. Menezes, L. Menezes, V. Moura, and R.R.A. Corte: Eng. Failure Analysis, 2009, vol. 16, pp. 552-57.

27. S.S.M. Tavares, V. Moura, V.C. da Costa, M.L.R. Ferreira, and J.M. Pardal: Mater. Characterization, 2009, vol. 60, pp. 573-78.

28. A. Ben Rhouma: Ph.D. Thesis, University of Tunis el Manar, Tunisia, 2002.

29. H. Sidhom: Ph.D. Thesis, University of Paris XI, Paris, 1990. 